\title{
Gene expression analysis of common carp (Cyprinus carpio L.) lines during Cyprinid herpesvirus 3 infection yields insights into differential immune responses
}

\author{
Krzysztof Ł. Rakus ${ }^{\mathrm{a}, 1}$, Ilgiz Irnazarow ${ }^{\mathrm{a}, *}$, Mikołaj Adamek ${ }^{\mathrm{b}}$, Leonor Palmeira ${ }^{\mathrm{c}}$, Yuriko Kawana ${ }^{\mathrm{d}}$, \\ Ikuo Hirono ${ }^{\mathrm{d}}$, Hidehiro Kondo ${ }^{\mathrm{d}}$, Marek Matras ${ }^{\mathrm{e}}$, Dieter Steinhagen ${ }^{\mathrm{b}}$, Barbara Flasz ${ }^{\mathrm{a}}$, Graham Brogden ${ }^{\mathrm{b}}$, \\ Alain Vanderplasschen ${ }^{\mathrm{c}}$, Takashi Aoki ${ }^{\mathrm{d}}$ \\ ${ }^{a}$ Polish Academy of Sciences, Institute of Ichthyobiology E Aquaculture in Gołysz, Kalinowa 2, 43-520 Chybie, Poland \\ ${ }^{\mathrm{b}}$ Fish Diseases Research Unit, Centre for Infection Medicine, University of Veterinary Medicine in Hannover, Buenteweg 17, 30559 Hannover, Germany \\ ' Immunology-Vaccinology (B43b), Department of Infectious and Parasitic Diseases (B43b), Faculty of Veterinary Medicine, University of Liège, 4000 Liège, Belgium

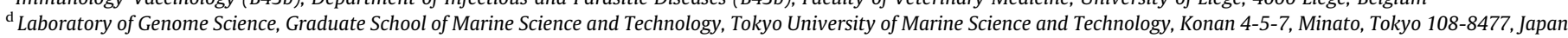 \\ ${ }^{e}$ Laboratory of Fish Diseases, National Veterinary Research Institute, Partyzantów 57, 24-100 Puławy, Poland
}

\section{A R T I C L E I N F O}

Article history:

Received 13 September 2011

Revised 7 December 2011

Accepted 13 December 2011

Available online 24 December 2011

\section{Keywords:}

Immune response

Antiviral response

Cytokines

T cell marker

Common carp

Cyprinid herpesvirus-3

CyHV-3

KHV

\begin{abstract}
A B S T R A C T
Cyprinid herpesvirus 3 (CyHV-3), also known as koi herpesvirus (KHV), is the etiological agent of a virulent and lethal disease in common and koi carp. This study aimed to determine the genetic basis underlying the common carp immune response to the CyHV-3 virus. Two common carp lines (R3 and K) were infected with CyHV-3 by immersion. The R3 line presented a 20\% higher survival rate compared to the $\mathrm{K}$ line and significantly lower viral loads as measured at day 3 post infection (p.i.). Microarray analysis using a common carp slides containing a number of 10,822 60-mer probes, revealed that 581 genes in line K (330 up-regulated, 251 down-regulated) and 107 genes in line R3 (77 up-regulated, 30 down-regulated), showed at least a 2 -fold difference in expression at day 3 p.i. compared to day 0 . Genes which showed at least a 4 -fold difference in expression in both lines were selected as potential markers of a CyHV-3 infection in common carp. Additionally, 76 genes showed at least 2-fold differentially expression between K and R3 lines at day 3 p.i. Significantly higher expression of several immune-related genes including number of those which are involve in pathogen recognition, complement activation, MHC class I-restricted antigen presentation and development of adaptive mucosal immunity was noted in more resistant R3 line. Further real-time PCR based analysis provided evidence for higher activation of CD8 ${ }^{+}$ $\mathrm{T}$ cells in R3 line. This study uncovered wide array of immune-related genes involved into antiviral response of common carp toward CyHV-3. It is also demonstrated that the outcome of this severe disease in large extent could be controlled by genetic factors of the host.
\end{abstract}

(c) 2011 Elsevier Ltd. All rights reserved.

\section{Introduction}

Cyprinid herpesvirus 3 (CyHV-3), also known as koi herpesvirus (KHV), is the etiological agent of a highly contagious and extremely virulent disease of common carp (Cyprinus carpio L.) and its ornamental koi varieties (Bretzinger et al., 1999; Hedrick et al., 2000; Michel et al., 2010; Pokorova et al., 2005). The mortality rate in affected ponds is as high as 70-95\%, causing very large economic losses in fish farms in many countries worldwide. CyHV-3 is a member of the Alloherpesviridae family comprising of piscine and

\footnotetext{
* Corresponding author. Tel.: +48 3385615 51; fax: +48 338589292.

E-mail addresses: ilgiz.irnazarow@fish.edu.pl, ilgiz.irnazarow@golysz.pan.pl (I. Irnazarow).

1 Present address: Immunology-Vaccinology (B43b), Department of Infectious and Parasitic Diseases (B43b), Faculty of Veterinary Medicine, University of Liège, 4000 Liège, Belgium.
}

amphibian herpesviruses (Davison et al., 2009; Waltzek et al., 2009). The genome of CyHV-3 is a 295-kb, linear, double-stranded DNA molecule, encoding for 156 potential protein-coding open reading frames (ORFs). The CyHV-3 genome is packaged within an icosahedral capsid which is surrounded by a proteinaceous tegument and finally by a host-derived lipid envelope containing virus glycoproteins. The sequence analysis of the whole genome of three CyHV-3 strains isolated in Israel (CyHV-3 I), Japan (CyHV-3 J) and United States (CyHV-3 U) revealed high sequence identity between the strains (Aoki et al., 2007).

Knowledge about immune mechanisms and immunological traits that can correlate with disease resistance in fish, is essential for the development of prophylactic strategies (such as vaccination) as well as for the development of more resistant strains by the use of molecular marker assisted selection. Genetic differences in resistance to CyHV-3 of different carp crosses has been reported (Dixon et al., 2009; Ødegård et al., 2010; Rakus et al., 2009; Shapira 
et al., 2005). However, to the best of our knowledge the number of studies on immune responses of carp against CyHV-3 is very limited. Perelberg et al. (2008) described the different kinetics of anti-CyHV-3 antibody formation in the serum of Koi kept at different temperatures and exposed to CyHV-3. It was shown that protection against CyHV-3 is proportional to the titer of specific antibodies during the primary infection. Nevertheless, no studies provided further insights in the immune response of carp against CyHV-3 using DNA microarray and real-time quantitative PCR.

In general, in vivo studies in human and other mammals have shown that the innate immune response against herpesviruses mostly include an activation of natural killer (NK) cells, the production of type I interferons (IFN) and interleukin-15 (IL-15) (Mossman and Ashkar, 2005) whereas the adaptive immune response includes an activation of both $\mathrm{CD}^{+}$and $\mathrm{CD} 4^{+} \mathrm{T}$ cells as well as the production of specific anti-viral antibodies (Chan et al., 2011; Wills et al., 2007). However, the genomes of many herpesviruses contain multiple genes that code for various proteins which counteract different aspects of the host immune response and involved in immune evasion processes. In the CyHV-3 genome, such candidate genes are ORF12, ORF16, and ORF134 which respectively code for a TNF receptor homolog, a potential G protein-coupled receptor and an IL-10 homolog (Michel et al., 2010).

In recent years, many genes encoding different immuno-regulatory peptides of the innate and the adaptive immune system as well as markers of immune cells have been discovered in teleost fish, including common carp. The teleost thymus, head kidney and spleen are considered as the major lymphoid organs (Rombout et al., 2005) and represent suitable sources for immune cells which respond to pathogen challenge. A genome-wide analysis of gene expression in cells derived from lymphoid organs would therefore allow a measurement of the expression pattern of a large number of genes with immune-related functions and of genes with currently unknown functions. Following the expression pattern at different time points during an infection of carp with CyHV-3 should therefore lead to a better understanding of the mechanisms of immune responses of carp to this virus, and will be very useful for development of future vaccines.

The present study describes for the first time a transcriptional analysis of immune-related genes of common carp during CyHV3 infection. We investigated gene expression differences between two lines of common carp that showed differences in both survival rates and viral loads during CyHV-3 infection. Our results demonstrate that differences in resistance of various genetic groups of fish could be associated with variations in the expression of selected immune-related genes. We also describe a group of genes which can serve as potential markers of an infection of common carp with CyHV-3.

\section{Materials and methods}

\subsection{Fish}

European common carp (Cyprinus carpio carpio L.) used in this study included four groups of carp: 2 lines ( $\mathrm{K}$ and $\mathrm{R} 3$ ) and 2 crosses between them (KxR3 and R3xK) (Irnazarow, 1995). Fish were obtained from the Institute of Ichthyobiology and Aquaculture in Gołysz (Poland). Each group was grown in aquaria with UV treated recirculating water and bio-filters. The total capacity of the system was $3 \mathrm{~m}^{3}$ and the water temperature was maintained at $21 \pm 1^{\circ} \mathrm{C}$. Daily feeding with commercial carp pellets (Aller Aqua, Poland) was applied at $3-5 \%$ body weight per day. Before the challenge experiments, fish (mean weight $\pm \mathrm{SD}=120 \mathrm{~g} \pm 38 \mathrm{~g}$ ) from the four genetic groups were randomly sampled, marked by fin clipping and transported to the Laboratory of Fish Diseases, National Veter- inary Research Institute in Puławy (Poland). Once there, fish were divided into two experimental groups: (i) mortality recording group ( $n=30$ fish/line and cross), and (ii) gene expression study group ( $n=40 \mathrm{fish} /$ line $\mathrm{K}$ and $n=28 \mathrm{fish} /$ line R3), and kept in two separate 8001 tanks. In addition, a control group (non-infected) was kept in a third 8001 tank ( $n=10$ fish/line and cross). Daily feeding with carp pellets at $3 \%$ body weight per day was applied. The water temperature was $23 \pm 1{ }^{\circ} \mathrm{C}$ in the mortality recording group and $21 \pm 1^{\circ} \mathrm{C}$ in the gene expression study group. Fish were allowed to acclimatize to the new recirculating system for a period of 4 weeks. No mortalities were observed during the acclimatization period.

\subsection{Cells and virus}

C. carpio brain (CCB) cells (Neukirch et al., 1999) were cultured in minimum essential medium (Gibco, Germany) containing $4.5 \mathrm{~g} /$ liter glucose (D-glucose monohydrate), 10\% fetal calf serum (FCS), Penicillin (200 i.u./ml), Streptomycin $(0.2 \mathrm{mg} / \mathrm{ml})$, and $1 \% \mathrm{MEM}$ non-essential amino acid solution (SIGMA, Germany). The cells were cultured at $22{ }^{\circ} \mathrm{C}$ in a humid atmosphere containing $5 \%$ $\mathrm{CO}_{2}$. $\mathrm{CCB}$ cultures were inoculated with CyHV-3 virus isolated in the Laboratory of Fish Disease, National Veterinary Research Institute in Puławy (Poland) from infected common carp in 2005 (passage no. 4). Infected $\mathrm{CCB}$ cultures were incubated at $22{ }^{\circ} \mathrm{C}$ in a humid atmosphere containing $5 \% \mathrm{CO}_{2}$ for 10 days and examined for cytopathic effect (CPE). Medium from infected cells including the virus was harvested and used for infection of the fish. The virus titer of the original virus suspension, given as tissue culture infective dose $\left(\mathrm{TCID}_{50} / \mathrm{ml}\right)$, was estimated by the method of Reed and Muench (1938). This titer was $8 \times 10^{4} \mathrm{TCID}_{50} / \mathrm{ml}$.

\subsection{Fish challenge and sampling protocol}

Fish were infected with the CyHV-3 virus by bath immersion challenge for $1 \mathrm{~h}$ at $22^{\circ} \mathrm{C}$, in small plastic containers containing tank water with virus suspension $\left(3.2 \times 10^{2} \mathrm{TCID}_{50} / \mathrm{ml}\right.$ in the final volume of water), and subsequently returned to their original tanks. The same treatment was applied to the control fish, but the water contained medium harvested from uninfected CCB cultures. For the mortality recording group, fish were observed three times per day over a period of 32 days. Moribund fish were removed from the tanks and the kidney and fin clips were collected and stored in 96\% EtOH until DNA extraction. Fish from the gene expression study group ( $n=5 /$ line/sampling point) were sampled on days $0,1,3,5$ and 14 post infection (p.i.). An additional $n=5$ fish/line were sampled at day 3 p.i. Organs (head kidney, spleen, kidney, liver, skin, gills, posterior gut (beginning part), and anterior gut (ending part)) were collected and divided into two parts. One part was placed into empty, sterile tubes, immediately frozen in liquid nitrogen and stored at $-80^{\circ} \mathrm{C}$. The second part was placed into tubes containing RNAlater (Qiagen, Germany) and stored at $4{ }^{\circ} \mathrm{C}$ until RNA extraction. In addition, blood was collected and serum was stored at $-80^{\circ} \mathrm{C}$ until complement activation assay.

\subsection{Detection and quantitation of $C y H V-3$}

Virus detection was performed by PCR amplification of a CyHV3 genome fragment localized between ORF55 and ORF56, using the M-KHV1-F and M-KHV1-R primers (Table 1). In short, DNA was isolated from $25 \mathrm{mg}$ of kidney samples from infected and control fish using the Genomic Mini Kit (A\&A Biotechnology, Poland) according to the manufacturer's manual. Amplification of the target PCR product was carried out in $20 \mu$ of reaction mix using 200-300 ng of total DNA, $200 \mathrm{nM}$ of each primer, $200 \mu \mathrm{M}$ of each dNTP, $1.5 \mathrm{mM} \mathrm{MgCl} 2$, 1x Flexi Buffer, and 0.5 units of GoTaq Flexi 
Table 1

Primers and probes sequences.

\begin{tabular}{|c|c|c|}
\hline $\begin{array}{l}\text { Primer/probe } \\
\text { name }\end{array}$ & Primer/probe sequence $\left(5^{\prime} \rightarrow 3^{\prime}\right)$ & $\begin{array}{l}\text { Accession } \\
\text { No. }\end{array}$ \\
\hline \multicolumn{3}{|c|}{ Primers and probes for detection and quantification of $\mathrm{CyHV}-3$} \\
\hline M-KHV1-F & TACCGAAACACGAAACACTTGCTC & AY660950 \\
\hline M-KHV1-R & CTCTTTACCCAGGAGGACCAGAC & \\
\hline KHV-86F & GACGCCGGAGACCTTGTG & AF411803 \\
\hline KHV-163R & CGGGTTCTTATTTTTGTCCTTGTT & \\
\hline KHV-109P & $\begin{array}{l}\text { (FAM) CTTCCTCTGCTCGGCGAGCACG } \\
\text { (BHQ1) }\end{array}$ & AF411803 \\
\hline EGFP1-F & GACCACTACCAGCAGAACAC & - \\
\hline EGFP10-R & CTTGTACAGCTCGTCCATGC & \\
\hline EGFP1-HEX & $\begin{array}{l}\text { (HEX) AGCACCCAGTCCGCCCTGAGCA } \\
\text { (BHQ1) }\end{array}$ & - \\
\hline \multicolumn{3}{|c|}{ Primers for RT-qPCR gene expression study } \\
\hline 40S-F & CCGTGGGTGACATCGTTACA & АB012087 \\
\hline 40S-R & TCAGGACATTGAACCTCACTGTCT & \\
\hline TCR $\alpha 1-\mathrm{F}$ & TTCACACAACATAATGCTGTAAATGA & EU025122 \\
\hline TCR $\alpha 1-\mathrm{R}$ & TTGACTGGATGATCCTGACATGC & \\
\hline TCR $\alpha 2-\mathrm{F}$ & CAGTGCGATATGCAGAACGAAGT & EU025123 \\
\hline $\mathrm{TCR} \propto 2-\mathrm{R}$ & TTGACTGGATGATCCTTGCTGA & \\
\hline $\mathrm{CD} 8 \propto 1 / 2-\mathrm{F}$ & TGCGCAGCCATGAACAACAATA & EU025118 \\
\hline CD8 $\alpha 1-\mathrm{R}$ & GCCATTGTTGTTGTCGATGGTA & \\
\hline $\mathrm{CD} 8 \alpha 2-\mathrm{R}$ & CGTAATCACTGGTGTTGCAGTT & EU025119 \\
\hline $\mathrm{CD} 8 \beta 1-\mathrm{F}$ & AATCAACGGCTCGGAAACTATC & EU025120 \\
\hline CD8 $\beta 1-R$ & CGCTCTCTGCCAGCGCTGTTACA & \\
\hline CD8 $\beta 2-F$ & AATCAATGGCTCGGAAGTTCTG & EO025121 \\
\hline $\mathrm{CD} 8 \beta 2-\mathrm{R}$ & CCAGCACTGTTGACATACACTAA & \\
\hline IL-1 $\beta 1-F$ & AAGGAGGCCAGTGGCTCTGT & AJ245635 \\
\hline IL-1 $\beta 1-R$ & CCTGAAGAAGAGGAGGCTGTCA & \\
\hline IL-10-F & CGCCAGCATAAAGAACTCGT & AB110780 \\
\hline IL-10-R & TGCCAAATACTGCTCGATGT & \\
\hline IL-12p35-F & TGCTTCTCTGTCTCTGTGATGGA & AJ580354 \\
\hline IL-12p35-R & CACAGCTGCAGTCGTTCTTGA & \\
\hline IL-6M17-F & CACATTGCTGTGAGGGTGAA & AY102633 \\
\hline IL-6M17-R & GCATCCATAGGCTTTCTGCT & \\
\hline IFN $\alpha \beta-F$ & GGCAGATATGGGACGGTGAG & EC393381 \\
\hline IFN $\alpha \beta-R$ & GTCCTCCACСTCAGCTTTGTC & \\
\hline
\end{tabular}

polymerase (Promega, USA). The PCR profile included an initial denaturation step at $94{ }^{\circ} \mathrm{C}$ for $3 \mathrm{~min}$, followed by 30 cycles of $95{ }^{\circ} \mathrm{C}$ for $30 \mathrm{~s}, 62^{\circ} \mathrm{C}$ for $30 \mathrm{~s}, 72{ }^{\circ} \mathrm{C}$ for $45 \mathrm{~s}$, and a final extension step at $72{ }^{\circ} \mathrm{C}$ for $7 \mathrm{~min}$. PCRs were performed using a MJ Research PTC-200 thermocycler (Biorad, USA). PCR products were detected on a $1 \%$ agarose gel with ethidium bromide staining and visualized using a TFX-35 M UV transilluminator (Vilber Lourmat, France).

Virus quantitation was performed by real-time TaqMan PCR as described by Gilad et al. (2004) with modifications. The kidneys from fish at day 0 and 3 p.i. were collected, snap frozen in liquid nitrogen and stored at $-80^{\circ} \mathrm{C}$ until further use. The DNA was isolated from $25 \mathrm{mg}$ of tissue after mechanical lyses in QIAgen Tissuelyser II (Qiagen, Germany) with the QIAamp DNA Mini Kit (Qiagen, Germany) according to the manufacturer's manual. After isolation the quantity of DNA was evaluated in a Nanodrop ND-1000 spectrophotometer and the samples were diluted to $50 \mathrm{ng} / \mu \mathrm{l}$ and stored at $-80^{\circ} \mathrm{C}$. Real-time TaqMan PCR was used to amplify a fragment of the CyHV-3 genome (Accession No. AF411803) by the use of KHV-86F and KHV-163R primers and the KHV-109P probe (see Table 1 ). In each sample, TaqMan PCR amplification control was also performed by the use of an INTYPE IC-DNA control (Labor Diagnostik Leipzig, Germany), EGFP1-F and EGFP10-R primers and the EGFP1-HEX probe (see Table 1). The real-time TaqMan PCR reaction mix contained 1x master mix (QuantiTect Multiplex PCR Kit, Qiagen, Germany), $800 \mathrm{nM}$ of each primer, $100 \mathrm{nM}$ of each fluorescent probe, $5 \times 10^{4}$ copies of INTYPE IC-DNA, and $250 \mathrm{ng}$ of DNA template. The real-time TaqMan PCR was performed on a Stratagene Mx 3005P thermocycler (Agilent, USA). Plasmid based virus copy quantification was performed using the product amplified with the primers KHV-86F and KHV-163R (Table 1), ligated into the pGEM-T Easy vector (Promega, USA) and propagated in JM109 competent Escherichia coli bacteria (Promega, USA). The plasmids were isolated by the alkalies-lyses method and purified with the Clean-Up Kit (A\&A Biotechnology, Poland) according to the manufacturer's protocol. A standard curve from $10^{2}$ to $10^{7}$ of gene copies was prepared and used for quantification of the viral load from each sample. The results are presented as the total number of virus copies per $250 \mathrm{ng}$ of DNA.

\subsection{RNA extraction and $C D N A$ synthesis}

For microarray analysis, the total RNA was isolated from head kidney samples using the RNeasy Mini Kit (Qiagen, Japan) according to the manufacturer's instructions. For real-time quantitative PCR analysis, the total RNA was isolated from spleen samples of the same individuals using the RNAiso Plus kit (Takara, Japan) including a second DNase treatment of isolated RNA (RNase-Free DNase, Promega, Japan). The concentration of RNA was measured by means of a spectrophotometer at $\mathrm{OD}_{260 \mathrm{~nm}}$. The purity of extracted RNA was determined as the $\mathrm{OD}_{260 \mathrm{~nm}} / \mathrm{OD}_{280 \mathrm{~nm}}$ ratio with expected values between 1.8 and 2.0. Total RNA was stored at $-80^{\circ} \mathrm{C}$ until use.

For microarray analysis, 200 ng of total RNA was used for synthesis and labeling of cDNA by using the Low Input Quick Amp Labeling Kit (Agilent Technologies, USA) following the manufacturer's instructions. The cDNA was labeled by cyanine 3-CTP (Cy3). For real-time quantitative PCR analysis, $1 \mu \mathrm{g}$ of RNA was used for the synthesis of cDNA by using the M-MLV cDNA synthesis System (Invitrogen, Japan) according to the manufacturer's instructions. cDNA samples were further diluted 40 times in nuclease-free water before use as the template in real-time quantitative PCR experiments.

\subsection{One-color microarray-based gene expression measurement and statistical analysis}

A microarray analysis was performed on head kidney samples of fish from lines $\mathrm{K}$ and $\mathrm{R} 3$ ( $n=4 \mathrm{fish} /$ line/sampling point) sampled at day 0 and day 3 after CyHV-3 infection. A custom microarray was designed for $8 \times 15 \mathrm{~K}$ glass slides (Agilent Technologies, USA). Common carp transcript clusters were derived from Genbank mRNA transcripts and EST sequences of $C$. carpio. Based on these sequences a number of 10,822 60 -mer probes were designed. In addition, a number of 15260 -mer probes were designed to target each of CyHV-3 annotated ORFs. Probe design was performed by Agilent. The arrays were hybridized with Cy3-labeled first strand cDNA in hybridization buffer. Hybridization was carried out for $17 \mathrm{~h}$ at $65^{\circ} \mathrm{C}$. After $17 \mathrm{~h}$, the glass slides were washed with GE Wash Buffer for 1 min at RT and subsequently with GE Wash Buffer 2 for 1 min at $37^{\circ} \mathrm{C}$ using the Low Input Quick Amp Labeling Kit (Agilent Technologies, USA). The two glass slides were dried and scanned immediately using a Gene Pix 4000B (Axon Instruments, USA).

Images obtained from scanning the slides were extracted to numerical data (.txt format) by GenePix Pro ver. 4.0 (Axon Instruments, USA) and analyzed in R using the 'limma' package from the Bioconductor project (Gentleman et al., 2004; R Development Core Team, 2011; Smyth, 2004). The single-channel arrays were first background corrected with the normexp method and an offset of 50 (Ritchie et al., 2007) and then normalized with a quantile normalization (Bolstad et al., 2003; Yang and Thorne, 2003). The experiment included four biological replicates with no dye swaps for each strain ( $\mathrm{K}$ and R3) and condition (day 0 and day 3 ). A linear model was fit to the data using a least squares method (Smyth, 2004). In order to identify the genes differentially expressed in each of the model's contrasts, an empirical Bayes moderated 
t-statistics was used (Smyth, 2004). A moderated F-statistic (F) combining the $t$-statistics for all the contrasts was also used to infer genes bearing differential expression in at least one of the contrasts (Smyth, 2004). The resulting $p$-values were corrected for multiple testing with Benjamini-Hochberg's procedure to control for a false discovery rate (Benjamini and Hochberg, 1995). Genes with 2 -fold changes or greater were considered differentially regulated and with adjusted $p$-values below 0.05 were considered significantly differentially regulated.

The raw and normalized data resulting from this experiment have been deposited in the NCBI Gene Expression Omnibus (GEO) database with Accession Nos. GSM754677-GSM754692, and the microarray design has been deposited to GEO with accession number GPL13819, following MIAME guidelines (Brazma et al., 2001).

\subsection{Real-time quantitative $P C R(R T-q P C R)$ and statistical analysis}

RT-qPCR using SYBR Green I technology was performed using an Applied Biosystems 7300 instrument (Applied Biosystems, USA) with the Fast Start Universal SYBR Green Master (ROX) (Roche Diagnostics GmbH, Germany) as detection chemistry. The primers used for RT-qPCR were previously described by Forlenza (2009) and are listed in Table 1. The master-mix for each RT-qPCR run was prepared as follows: 1x Fast Start Universal SYBR Green Master (ROX), $200 \mathrm{nM}$ of each primer, $5.0 \mu \mathrm{l}$ of $40 \mathrm{x}$ diluted cDNA and sterile water to a final volume of $20 \mu \mathrm{l}$. The amplification program included an initial denaturation at $95^{\circ} \mathrm{C}$ for $10 \mathrm{~min}$, followed by 40 cycles with denaturation at $95^{\circ} \mathrm{C}$ for $15 \mathrm{~s}$ and annealing and elongation in one step at $60{ }^{\circ} \mathrm{C}$ for $1 \mathrm{~min}$. At the end, the dissociation stage was performed as follows: $95^{\circ} \mathrm{C}$ for $15 \mathrm{~s}, 60^{\circ} \mathrm{C}$ for $30 \mathrm{~s}$, and $95{ }^{\circ} \mathrm{C}$ for $15 \mathrm{~s}$. Fluorescence data from RT-qPCR experiments were analyzed using Applied Biosystems 7300 software and exported to Microsoft Excel. The threshold cycle $(\mathrm{Ct})$ was determined using the Auto method for all runs. The expression of analyzed genes was calculated using the $2^{-\Delta \Delta C t}$ method (Livak and Schmittgen, 2001). The $40 \mathrm{~S}$ ribosomal protein S11 was used as a reference gene.

Significant differences $(p \leqslant 0.05)$ in RT-qPCR gene expression between CyHV-3 infected and uninfected samples, as well as between fish from lines $\mathrm{K}$ and $\mathrm{R} 3$ at each sampling time point were assessed using one-way ANOVA in cases where the data were normally distributed, or with the non-parametric Kruskal-Wallis test when not. All the statistical analysis was performed using MedCalc version 9.3.0.0 software.

\subsection{Complement hemolytic activity in the classical pathway (CH50) analysis}

\subsubsection{Carp anti-SRBC serum}

One individual of $C$. carpio (500 g) was injected (i.p.) with $10^{9}$ SRBC in PBS. Four weeks later a booster injection $\left(10^{9}\right)$ was given. Ten days later, fish were bled for hemolysin and carp anti-SRBC antibody was determined by haemagglutination test. Complement was inactivated by incubation at $45^{\circ} \mathrm{C}$ for $15 \mathrm{~min}$. Hemolysin was stored at $-80^{\circ} \mathrm{C}$. Optimal dilution of hemolysin for SRBC sensitization 1:800 (v/v) was determined according to Yano (1992).

\subsubsection{Hemolytic assay}

The gelatin veronal buffer $\left(\mathrm{GVB}^{2+}\right)$ containing $10 \mathrm{mM} \mathrm{Mg}^{2+}$, $1 \mathrm{mM} \mathrm{Ca}^{2+}$, pH 7.6 was used for the assay. Test serum samples were diluted $1: 20(\mathrm{v} / \mathrm{v})$ in the $\mathrm{GVB}^{2+}$ buffer and the volumes of $15,45,75$ and $97.5 \mu \mathrm{l}$ were placed in triplicate in the U-bottom 96 well plates. Samples were combined with $\mathrm{GVB}^{2+}$ buffer to the final volume of $97.5 \mu \mathrm{l}$. Next, $15 \mu \mathrm{l}$ of sensitized SRBC in $\mathrm{GVB}^{2+}$ was added. A positive control (100\% hemolysis) reference con- tained water and sensitized SRBS, the negative control contained sensitized SRBC and $\mathrm{GVB}^{2+}$ buffer. Finally the control sensitization of SRBC with non-immune pooled carp serum and a standard complement sample (serum pool) for correction of plate differences were included.

The plate were incubated for $60 \mathrm{~min}$ at $25^{\circ} \mathrm{C}$ and centrifuged (Labofuge II, Heraeus, Germany) for $5 \mathrm{~min}$ at $500 \mathrm{~g}$ to spin down SRBC. The supernatant in each well was carefully aspirated and placed in a new flat bottom microtitre plate (F.L. Medical S.r.l., Italy). The optical density of the supernatant was measured at $540 \mathrm{~nm}$. A lysis curve was obtained by plotting the percentage of hemolysis against the volume of serum; the volume which yielded 50\% hemolysis was determined and used for calculating the complement activity of the samples (CH50 unit/ml) according to Yano (Yano, 1992).

\section{Results}

\subsection{CyHV-3 challenge and virus quantification}

After infection of common carp with CyHV-3, the first mortalities were recorded on day 6 p.i. in line $\mathrm{K}(n=5)$ and cross R3xK $(n=1)$ carp. The last mortalities were recorded on day 18 p.i. The highest cumulative mortality (76\%) was observed in line $\mathrm{K}$ and the lowest (56\%) in line R3. The mortality of crosses KxR3 and R3xK were $62 \%$ and $66 \%$, respectively.

The presence of CyHV-3 was confirmed by PCR in all infected fish (dead and the survivors). All control fish were negative for CyHV-3. The quantitative analysis of viral load by real-time TaqMan PCR was performed on a group of fish from line K and R3 dedicated for microarray analysis. At day 0 , no virus DNA was revealed in fish from both lines ( $n=5 \mathrm{fish} /$ line). At day 3 p.i. the number of virus DNA copies was significantly higher in the K line (higher mortality; higher susceptibility) than in the R3 line (lower mortality; moderate susceptibility) ( $n=10$ fish/line) (Fig. 1 ).

3.2. Differentially expressed genes between day 0 and day 3 p.i. in line $K$ (susceptible) and $R 3$ (moderately susceptible) as revealed by microarray analysis

Changes in gene expression between day 0 and day 3 after CyHV-3 infection was analyzed in each line separately. At day 3 p.i., 581 genes in line K (330 up-regulated, 251 down-regulated) and 107 genes in line R3 (77 up-regulated, 30 down-regulated), were at least 2-fold differentially expressed compared to day 0 . Among them, genes which were at least 4-fold differentially expressed in both lines were selected as potential markers of an infection of common carp by CyHV-3. This group includes 17 upregulated and only 1 down-regulated genes (Table 2). Among upregulated genes, there were 8 immune-related genes (47\%): two interferon-inducible protein Gig-1 like genes, signal transducer and activator of transcription 1 (STAT1), novel protein belonging to the chemokine CC superfamily, ubiquitin-like protein, ubiquitin-specific protease-18, galectin-3-binding protein $\mathrm{A}$, and suppressor of cytokine signaling 1 . Only one gene, a novel protein containing a lectin C-type domain, was significantly down-regulated in both lines.

3.3. Differentially expressed genes between line $K$ (susceptible) and $R 3$ (moderately susceptible) at day 3 p.i. as revealed by microarray analysis

Microarray analysis revealed no significant differences in gene expression between line $\mathrm{K}$ and R3 at day 0 . Three days after CyHV-3 infection, 76 genes showed at least 2-fold difference in 
expression between two lines. In line R3, 55 genes were expressed significantly higher compared to line K. Twenty-two of them were immune-related genes (40\%). Comparatively, 21 genes were expressed significantly higher in line $\mathrm{K}$ compared to line R3, including six immune-related genes (29\%) (Table 3 ).

A more detailed analysis of the nature of expression ratios for these 55 genes ( $\mathrm{R} 3>\mathrm{K}$ variant), between day 3 and day 0 in both lines revealed that in most of the cases the difference was a result of down-regulation of gene expression in line $\mathrm{K}$, rather than an upregulation of gene expression in line R3, during the course of infection. In the other 21 genes ( $\mathrm{R} 3<\mathrm{K}$ variant), most of the changes resulted from an up-regulation of gene expression in line $\mathrm{K}$ during the course of infection (data not shown).

\subsection{Differential complement activation in the classical pathway} (CH50) between lines $K$ (susceptible) and $\mathrm{R} 3$ (moderately susceptible) during CyHV-3 infection

Complement hemolytic activity in the classical pathway ( $\mathrm{CH} 50)$ measured in line $\mathrm{K}$ maintained the same level during course of observation with the exception of day 1 p.i. when it was significantly lower as compared to day 0 . In contrary, carp from line R3 showed significantly elevated activity of complement at day 5 p.i. Line R3 presented significantly higher level of complement activation compared to line K at day 1 and 5 p.i. (Fig. 2). Due to limited number of fish in the R3 carp we could not measure $\mathrm{CH} 50$ values of the complement at day 14 p.i.

3.5. Differential kinetic of the expression of $T$ cell markers between lines $\mathrm{K}$ (susceptible) and $\mathrm{R} 3$ (moderately susceptible) during $\mathrm{CyHV}-3$ infection as revealed by $R T-q P C R$

The kinetics of gene expression of T cell markers TCR $\alpha 1$, TCR $\alpha 2$, CD8 $\alpha 1, C D 8 \alpha 2, C D 8 \beta 1$ and CD8 $\beta 2$ were determined in spleen samples derived from fish from the lines K and R3 ( $n=4$ fish/line/sampling point). Samples were collected over a period of 5 (line R3) to 14 (line K) days after CyHV-3 infection and analyzed by RT-qPCR. At day 14 p.i. gene expression in line R3 was not investigated due to the limited number of fish (Fig. 3).

Challenge with CyHV-3 significantly up-regulated the expression of TCR $\alpha 1$ and TCR $\alpha 2$ genes in fish from line R3 at day 1 p.i. By day 5 p.i., however, the expression of these genes was significantly down-regulated. In fish from line $\mathrm{K}$ we did not observe any differences in expression of TCR $\alpha 1$ during infection but the expression of the TCR $\alpha 2$ gene was significantly down-regulated at day 3 p.i. and up-regulated by day 14 p.i. In addition, both genes - TCR $\alpha 1$ and TCR $\alpha 2$, were expressed on significantly higher level in line $\mathrm{R} 3$ compare to line $\mathrm{K}$ at day 1 and 3 p.i.

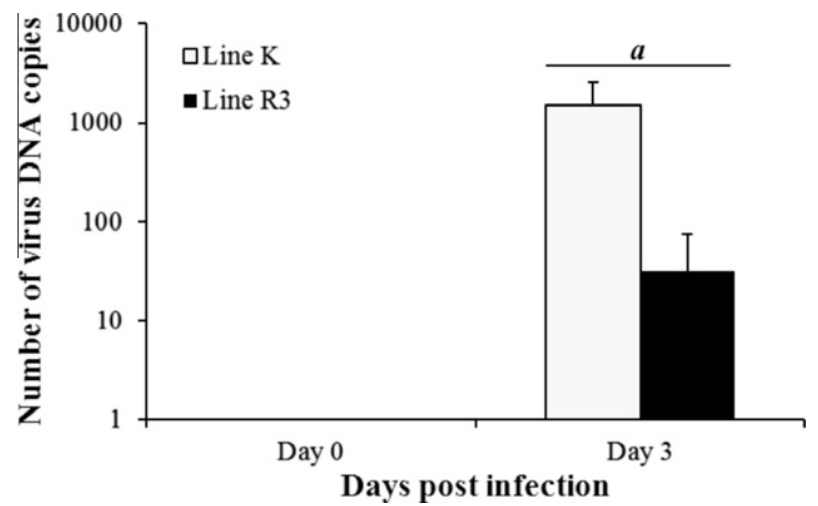

Fig. 1. CyHV-3 load in the kidney of carp from line $K$ and $R 3$ as measured by TaqMan-qPCR at day 0 and 3 p.i. Data are shown as mean + SD of $n=5$ fish (day 0 ) and $n=10$ fish (day 3 p.i.). Symbol $(\underline{a})$ indicates statistical difference $(p<0.05)$ in the viral loads between fish from 2 lines (K vs. R3)
Expression of CD8 $\beta 1$ was significantly up-regulated in line R3 at day 1,3 and 5 p.i. and in line $K$ at day 5 p.i. In addition, at day 1 p.i. expression of this gene was significantly higher in line R3 than in line $\mathrm{K}$. The challenge with CyHV-3 did not significantly change the expression level of the CD8 $\beta 2$ gene in carp from line R3, while the expression of this gene was significantly down-regulated in carp from line $\mathrm{K}$ at 3 days p.i. No significant differences were detected in the expression of CD8 $\alpha 1$ and $C D 8 \alpha 2$ genes in carp from both lines $\mathrm{K}$ and $\mathrm{R} 3$ during the challenge with CyHV-3.

\subsection{Differential kinetic of the expression of cytokine genes between line $\mathrm{K}$ (susceptible) and $\mathrm{R} 3$ (moderately susceptible) during CyHV-3 infection as revealed by $R T-q P C R$}

The kinetics of gene expression of the cytokines IL-1 $\beta 1$, IL-10, IL-12p35, IL-6M17 and IFN $\alpha \beta$ were determined in spleen samples derived from fish from the lines $\mathrm{K}$ and $\mathrm{R} 3$ ( $n=4 \mathrm{fish} /$ line/sampling point). Samples were collected over a period of 5 (line R3) to 14 (line K) days after CyHV-3 infection and analyzed by RT-qPCR. At day 14 p.i. gene expression in line R3 was not investigated due to the limited number of fish (Fig. 4).

Challenge with CyHV-3 significantly up-regulated the IL-1ß1 gene expression in individuals from line R3 at day 5 p.i and from line K on days 3 and 5 p.i. Significant differences in the expression of IL-1 $\beta 1$ between fish from lines K and R3 were however observed at day 5 p.i. Indeed, expression level of IL-1 $\beta 1$ in carp from line R3 was about five times higher than in carp from line $\mathrm{K}$ at that time point. At day 14 p.i. the expression of IL-1 11 in line K carp was on the same level as in the fish sampled at day 0 . Challenge with CyHV-3 also induced significant up-regulation of IL-10 in line R3 at day 5 p.i. and in line $\mathrm{K}$ at day 14 p.i. At day 3 p.i. the expression of this gene was significantly higher in fish from line R3 than in line $\mathrm{K}$, although not significantly different when compared to individuals sampled at day 0 due to high individual variations in line R3.

Expression of IL-12p35 was down-regulated during the CyHV-3 infection in line $K$ on days 3 and 5 p.i. In those sampling points the expression of IL-12p35 was significantly higher in line R3 than in line K. We also observed an up-regulation of IL-12p35 expression in line R3 at day 3 p.i., although not statistically significant due to high individual variations. Challenge with CyHV-3 induced an upregulation of IL-6M17 in line R3 on days 1,3 and 5 p.i., although these differences were significant only at day 5 p.i. because of high individual variations at earlier sampling points. At day 5 p.i. the expression of this gene was also significantly higher in line R3 as compared to line K. No significant differences in expression of the IFN $\alpha \beta$ gene was detected in lines K and R3 during the infection with CyHV-3.

\section{Discussion}

Recently, several studies described that variation in disease resistance between different populations of fish can be correlated with differences in expression profiles of immune-related genes (Baerwald et al., 2008; Bilodeau-Bourgeois et al., 2008; Yasuike et al., 2010). In this work we studied the immune response of two different lines of common carp ( $\mathrm{K}$ and $\mathrm{R} 3$ ) infected with CyHV-3 by bath immersion. The two carp lines presented a $20 \%$ difference in survival rate and significant difference in viral loads at day 3 p.i.

4.1. CyHV-3 infection induces the up-regulation of immune-related genes and activation of type I IFNs-dependent pathways in both carp lines

Microarray analysis revealed that infection of common carp with CyHV-3 resulted in changes of expression of many genes at 
Table 2

Differently expressed genes from the carp head kidney during CyHV-3 infection. Listed below are genes which showed at least a 4 -fold difference in expression between day 0 and day 3 p.i. in lines K and R3 ( $p<0.05$ ). Immuno-related genes are printed in bold.

\begin{tabular}{|c|c|c|c|}
\hline \multirow{2}{*}{$\begin{array}{l}\text { Putative gene product [Species of best } \\
\text { BLAST hit] }\end{array}$} & \multirow[t]{2}{*}{ Accession } & \multicolumn{2}{|c|}{ Fold change } \\
\hline & & $\begin{array}{l}\mathrm{K} \\
\text { line }\end{array}$ & $\begin{array}{l}\text { R3 } \\
\text { line }\end{array}$ \\
\hline \multicolumn{4}{|l|}{ Up-regulated genes } \\
\hline KIAA0650-like protein [Danio rerio] & AAW34265 & 16.0 & 14.2 \\
\hline $\begin{array}{l}\text { Novel protein belongs to chemokine CC } \\
\text { superfamily [Danio rerio] }\end{array}$ & CAM14364 & 29.7 & 12.9 \\
\hline Ubiquitin-like protein [Carassius auratus] & AAF17609 & 10.5 & 11.2 \\
\hline Zgc:112492 protein [Danio rerio] & AAI64862 & 25.9 & 10.1 \\
\hline Galectin-3-binding protein A & Q24JV9 & 11.0 & 8.6 \\
\hline $\begin{array}{l}\text { Signal transducer and activator of } \\
\text { transcription } 1 \text { (STAT1) [Carassius } \\
\text { auratus] }\end{array}$ & AAO 88245 & 11.4 & 7.8 \\
\hline $\begin{array}{l}\text { Novel protein similar to vertebrate } \\
\text { phosopholipid scramblase family [Danio } \\
\text { rerio] }\end{array}$ & CAN88616 & 10.8 & 6.3 \\
\hline Novel protein [Danio rerio] & CAM14206 & 4.6 & 5.8 \\
\hline $\begin{array}{l}\text { Interferon-inducible protein Gig1-like } \\
\text { [Danio rerio] }\end{array}$ & XP_002660606 & 4.2 & 5.4 \\
\hline $\begin{array}{l}\text { Ubiquitin specific protease } 18 \text { [Carassius } \\
\text { auratus] }\end{array}$ & ABC86864 & 4.9 & 5.2 \\
\hline $\begin{array}{l}\text { Poly (ADP-ribose) polymerase family, } \\
\text { member 14-like [Danio rerio] }\end{array}$ & XP_691115 & 10.1 & 4.9 \\
\hline $\begin{array}{l}\text { Novel protein similar to vertebrate hect } \\
\text { domain and RLD } 3 \text { (HERC3) [Danio rerio] }\end{array}$ & CAX12367 & 4.1 & 4.4 \\
\hline $\begin{array}{l}\text { Suppressor of cytokine signaling } 1 \\
\text { [Ctenopharyngodon idella] }\end{array}$ & ADA60714 & 6.0 & 4.3 \\
\hline $\begin{array}{l}\text { Interferon-inducible protein Gig1-like } \\
\text { [Danio rerio }]\end{array}$ & XP_001336615 & 5.8 & 4.1 \\
\hline $\begin{array}{l}\text { Hypothetical protein LOC557223 [Danio } \\
\quad \text { rerio] }\end{array}$ & XP_685328.3 & 5.6 & 6.3 \\
\hline $\begin{array}{l}\text { Hypothetical protein LOC335618 [Danio } \\
\text { rerio] }\end{array}$ & XP_001920014 & 4.5 & 4.9 \\
\hline Hypothetical protein [Danio rerio] & XP_699055 & 5.7 & 4.5 \\
\hline Down-regulated genes & & & \\
\hline $\begin{array}{l}\text { Novel protein containing a Lectin C-type } \\
\text { domain [Danio rerio] }\end{array}$ & CAX14642 & -11.3 & -5.9 \\
\hline
\end{tabular}

day 3 p.i. We were able to identify group of genes which showed at least a 4-fold difference in expression in both lines. These genes serve number of potential CyHV-3 infection markers of common carp. Such markers of infection can be useful, for example in the design and evaluation of new vaccines, as well as for studying immune responses and host-pathogen interactions of common carp. Our results clearly showed the importance of type I IFNs activated pathways in the response of carp against CyHV-3. Several genes involved in the type I IFN response, including the gene encoding for signal transducer and activator of transcription 1 (STAT1) protein, as well as type I IFN-inducible genes (Gig1-like protein, ubiquitinlike protein (ISG15) and ubiquitin specific protease 18) were highly up-regulated in both carp lines.

The type I IFN system is involved in the first line of defense against viral infections. The antiviral effect is exerted through the binding of type I IFNs to specific cell-surface receptors and triggering signal transduction through the JAK-STAT signal transduction pathway, which in-turn induces the expression of a large number of IFN-stimulated genes, some of which encode antiviral proteins (Katze et al., 2002; Robertsen, 2006). STAT1 is one of the cytoplasmic transcription factors that mediate intracellular signaling in IFN-induced pathways. STAT1 expression was highly up-regulated in the kidney of salmon at day 6 and day 4 after injection with ISAV and IPNV, respectively (Collet et al., 2008). Gig1 is an IFN-inducible protein activated by JAK-STAT signal transduction pathway and seems to play an essential role in the host-defense response (Zhang and Gui, 2004).

Ubiquitin-like protein and ubiquitin specific protease 18 (USP18) were also highly up-regulated in both carp lines.
Ubiquitin-like proteins (Ubls) are small proteins related to ubiquitin, that all possess the same three-dimensional structure, and conjugated to diverse cellular proteins which results in degradation or modulation of the target protein's stability, function, and localization (Kerscher et al., 2006). The conjugation can be reversed by USP18, which is an IFN-inducible cysteine protease. In our study the highly up-regulated gene which showed the best BLAST hit with the goldfish ubiquitin-like protein sequence - IFN-stimulated gene 15 (ISG15) (Liu et al., 2002) - most probably represent the ISG15 homolog in common carp. In general, ISG15 is induce to a very high level by type I IFNs and can inhibit the replication of different viruses in human and mice. ISG15 play a role in ISGylation process, which unlike ubiquitinylation is an IFN-stimulated and regulated process and does not promote the degradation of the target protein but modulate the protein's function and activity (Harty et al., 2009). In addition, the secreted form of ISG15 exhibits immunomodulatory functions, inducing production of IFN $\gamma$ in T cells and stimulating NK cell proliferation and activity (D'Cunha et al., 1996). Several studies described the up-regulation of ISG15-like genes in fish in response to virus infection (reviewed in Verrier et al., 2011).

In addition to genes involved in the type I IFN response, two other immune-related genes (a novel protein belonging to the chemokine CC superfamily and suppressor of the cytokine signaling 1) were also very highly up-regulated in both lines during CyHV-3 infection. The members of the CC chemokine family are known to guide leukocytes to sites of infection and inflammation (Rossi and Zlotnik, 2000). It has been described that the number of leukocytes in carp blood increases 2.5 times in the first 2 days after a CyHV-3 infection and is about two times higher during 14 days of the clinical infection compared to control fish (Negenborn, 2009). The suppressor of the cytokine signaling 1 (SOCS1) belongs to the SOCS family that consists of eight members, designated SOCS1 to SOCS7 and CIS (cytokine-inducible SH2 domain protein), which are known to participate in negative feedback loops in cytokine receptor signaling by inhibiting a variety of signal transduction pathways (Starr et al., 1997). In mammals, the up-regulation of SOCS1 expression is mainly induced by interferons as well as by several other cytokines (Fenner et al., 2006). SOCS1 acts to inhibit the proinflamatory effect of IFNs and IL- 6 by suppressing signaling in response to these cytokines (Fenner et al., 2006). Different viruses, however, evolved mechanisms to induce SOCS expression in order to inhibit IFNs signaling and to reduce antiviral response of the host (Bode et al., 2003; Oshansky et al., 2009; Pothlichet et al., 2008; Zhao et al., 2007). Thus, the up-regulation of SOCS1 observed in our study might also indicates the presence of immune evading mechanisms of CyHV-3.

\subsection{Differentially expressed genes between carp lines $R 3$ and $K$ at day} 3 p.i. might result in differences in resistance to $\mathrm{CyHV}-3$

In our study we did not observe differences in gene expressions between lines $\mathrm{K}$ and R3 before an infection. However the microarray analysis revealed 76 genes at least 2-fold differentially expressed between the two lines at day 3 p.i. Seven annotated genes: fucolectin- 4 and fucolectin- 6 , fucose binding lectin, FBP32 precursor, FBP32 II precursor, class I metallothionein, and cysteine proteinase were expressed at a very high level in line R3 compared to line $\mathrm{K}$ (>7-fold change). These genes represent immune-related genes among which many play a role in pathogen recognition and activation of innate immune responses. Fucolectins (F-type lectins; lectins that bind fucose) have been described as immunerecognition molecules in both invertebrates (Saito et al., 1997) and vertebrates (Honda et al., 2000) and play a role in the regulation of cellular defense responses and in complement activation (Bianchet et al., 2002). Two other genes that can be involved in complement activation (proteins containing a C-type lectin domain and 
Table 3

Differently expressed genes in head kidney between CyHV-3 infected carp from line K and R3 at day 3 p.i. Immuno-related genes are printed in bold.

\begin{tabular}{|c|c|c|c|}
\hline $\begin{array}{l}\text { Putative gene product [Species of best } \\
\text { BLAST hit] }\end{array}$ & Accession & $\begin{array}{l}\text { Fold } \\
\text { change }\end{array}$ & $\begin{array}{l}p- \\
\text { value }\end{array}$ \\
\hline \multicolumn{4}{|l|}{ Line $R 3$ > line $K$ (55 genes) } \\
\hline Fucolectin-4 [Anguilla japonica] & ВАВ03526 & 10.4 & 0.0415 \\
\hline $\begin{array}{l}\text { Class I metallothionein [Cyprinus } \\
\text { carpio] }\end{array}$ & AAB61577 & 10.2 & 0.0185 \\
\hline FBP32 precursor [Morone chrysops] & АВB29990 & 10.2 & 0.0392 \\
\hline Cysteine proteinase [Cyprinus carpio] & AAA49207 & 9.0 & 0.0165 \\
\hline $\begin{array}{l}\text { Fucose binding lectin [Dicentrarchus } \\
\quad \text { labrax] }\end{array}$ & ACF94293 & 8.9 & 0.0415 \\
\hline Fucolectin-6 [Anguilla japonica] & ВАВ03528 & 8.9 & 0.0408 \\
\hline FBP32II precursor [Morone saxatilis] & ABB29991 & 7.9 & 0.0437 \\
\hline $\begin{array}{l}\text { Liver-basic fatty acid binding protein b } \\
\text { [Cyprinus carpio] }\end{array}$ & ACA64701 & 5.7 & 0.0295 \\
\hline $\begin{array}{l}\text { Neurotoxin/C59/Ly-6-like protein-like } \\
\text { [Danio rerio] }\end{array}$ & XP_002660983 & 5.4 & 0.0165 \\
\hline Alcohol dehydrogenase 8a [Danio rerio] & CAX14458 & 4.7 & 0.0165 \\
\hline Chemokine CCL-C25ab [Danio rerio] & BAF98246 & 4.3 & 0.0287 \\
\hline $\begin{array}{l}\text { Tyrosine-protein kinase receptor (Ntrk1 } \\
\text { protein) [Danio rerio] }\end{array}$ & AAI62577 & 4.2 & 0.0391 \\
\hline $\begin{array}{l}\text { Invariant chain like protein } 1 \text { [Cyprinus } \\
\text { carpio] }\end{array}$ & BAC53767 & 4.0 & 0.0300 \\
\hline 40 S ribosomal protein S23 [Salmo salar] & ACN10021 & 3.9 & 0.0403 \\
\hline $\begin{array}{l}\text { Novel protein containing a Lectin C- } \\
\text { type domain [Danio rerio] }\end{array}$ & CAX14642 & 3.5 & 0.0419 \\
\hline $\begin{array}{l}\text { Microfibrillar-associated protein 4- } \\
\text { like isoform } 1 \text { [Danio rerio] }\end{array}$ & XP_001340028 & 3.5 & 0.0267 \\
\hline Cystatin C (zgc:136227) [Danio rerio] & CAX14260 & 3.2 & 0.0221 \\
\hline Transgelin [Danio rerio] & AAI22181 & 3.1 & 0.0221 \\
\hline Keratin [Carassius auratus] & AAC38008 & 3.0 & 0.0165 \\
\hline $\begin{array}{l}\text { Extended synaptotagmin-like protein } 1 \mathrm{a} \\
\quad \text { [Danio rerio }]\end{array}$ & XP_695611 & 2.9 & 0.0391 \\
\hline $\begin{array}{l}\text { Keratin, type I cytoskeletal } 13 \\
\quad \text { [Anoplopoma fimbria] }\end{array}$ & ACQ58237 & 2.8 & 0.0165 \\
\hline Chemokine CCL-C25a [Danio rerio] & BAF98240 & 2.8 & 0.0204 \\
\hline $\begin{array}{l}\text { Immunoglobulin light chain [Cyprinus } \\
\text { carpio] }\end{array}$ & BAA76502 & 2.8 & 0.0463 \\
\hline Tiarin protein-like [Danio rerio] & XP_001335383 & 2.7 & 0.0428 \\
\hline Taurine transporter [Cyprinus carpio] & BAA89537 & 2.7 & 0.0249 \\
\hline $\begin{array}{l}\text { Cell division control protein } 42 \\
\text { [Oncorhynchus mykiss] }\end{array}$ & ACO07740 & 2.7 & 0.0165 \\
\hline $\begin{array}{l}\text { T cell antigen receptor alpha chain VJC } \\
\text { region [Cyprinus carpio] }\end{array}$ & BAD88986 & 2.6 & 0.0185 \\
\hline $\begin{array}{l}\text { Novel protein similar to vertebrate } \\
\text { arachidonate 5-lipoxygenase } \\
\text { (ALOX5) [Danio rerio] }\end{array}$ & CAX14764 & 2.6 & 0.0457 \\
\hline $\begin{array}{l}\text { Novel protein similar to vertebrate } \\
\text { NIMA-related kinase } 5 \text { (NEK5) [Danio } \\
\text { rerio] }\end{array}$ & CAQ15143 & 2.6 & 0.0489 \\
\hline si:dkey-211e20.10 [Danio rerio] & XP_002666423 & 2.6 & 0.0415 \\
\hline Death associated protein $1 \mathrm{~b}$ [Danio rerio] & AAI15169 & 2.6 & 0.0220 \\
\hline $\begin{array}{l}\text { B-2-microglobulin precursor [Salmo } \\
\text { salar] }\end{array}$ & ACI66331 & 2.6 & 0.0399 \\
\hline Id1 protein [Danio rerio] & AAH71286 & 2.5 & 0.0221 \\
\hline Zgc:153317 protein [Danio rerio] & AAI22237 & 2.5 & 0.0165 \\
\hline $\begin{array}{l}\text { Short prolactin receptor S1 [Cyprinus } \\
\text { carpio] }\end{array}$ & AAZ43193 & 2.5 & 0.0481 \\
\hline Nuclear protein 1-like [Danio rerio] & XP_002661973 & 2.5 & 0.0466 \\
\hline $\begin{array}{l}\text { cytochrome c oxidase subunit VIla } \\
\text { polypeptide 2-like (Zgc:153177) } \\
\text { [Danio rerio] }\end{array}$ & AAI24270 & 2.4 & 0.0451 \\
\hline $\begin{array}{l}\text { Invariant chain like protein } 2 \text { [Cyprinus } \\
\text { carpio] }\end{array}$ & BAC53768 & 2.3 & 0.0474 \\
\hline $\begin{array}{l}\text { Ribosomal RNA processing } 15 \text { homolog } \\
\text { [Danio rerio] }\end{array}$ & AAH46037 & 2.3 & 0.0466 \\
\hline CD3 $\gamma /$ delta [Cyprinus carpio] & ABC97370 & 2.2 & 0.0221 \\
\hline Midkine a [Carassius gibelio] & ABS19628 & 2.2 & 0.0399 \\
\hline $\begin{array}{l}\text { cysteine-rich protein } 1 \text { (Zgc:103738) } \\
\text { [Danio rerio] }\end{array}$ & AAI53560 & 2.2 & 0.0165 \\
\hline HLA-DPA1 protein [Danio rerio] & AAH74082 & 2.1 & 0.0416 \\
\hline $\begin{array}{l}\text { Bactericidal permeability-increasing } \\
\text { protein/lipopolysaccharide-binding } \\
\text { protein [Cyprinus carpio] }\end{array}$ & BAC56095 & 2.1 & 0.0442 \\
\hline Granulin [Carassius auratus] & ABD03952 & 2.1 & 0.0295 \\
\hline
\end{tabular}

Table 3 (continued)

\begin{tabular}{|c|c|c|c|}
\hline $\begin{array}{l}\text { Putative gene product [Species of best } \\
\text { BLAST hit] }\end{array}$ & Accession & $\begin{array}{l}\text { Fold } \\
\text { change }\end{array}$ & $\begin{array}{l}p- \\
\text { value }\end{array}$ \\
\hline $\begin{array}{l}\text { Alpha-1-microglobulin } \\
\quad[\text { Ctenopharyngodon idella] }\end{array}$ & ABW37743 & 2.1 & 0.0165 \\
\hline $\begin{array}{l}\text { Ribosomal protein L34 [Ictalurus } \\
\text { punctatus] }\end{array}$ & AAK95160 & 2.1 & 0.0461 \\
\hline $\begin{array}{l}\text { Unnamed protein product [Tetraodon } \\
\text { nigroviridis] }\end{array}$ & CAF92746 & 3.3 & 0.0165 \\
\hline Unnamed protein product [Danio rerio] & CAR80279 & 2.7 & 0.0165 \\
\hline $\begin{array}{l}\text { Unnamed protein product [Tetraodon } \\
\text { nigroviridis] }\end{array}$ & CAF95619 & 2.6 & 0.0391 \\
\hline $\begin{array}{l}\text { Unnamed protein product [Tetraodon } \\
\text { nigroviridis] }\end{array}$ & CAG10379 & 2.2 & 0.0408 \\
\hline $\begin{array}{l}\text { Hypothetical protein isoform } 1 \text { [Danio } \\
\text { rerio] }\end{array}$ & XP_002662640 & 5.6 & 0.0165 \\
\hline $\begin{array}{l}\text { Hypothetical protein LOC799904 [Danio } \\
\text { rerio] }\end{array}$ & NP_001077343 & 7.5 & 0.0489 \\
\hline $\begin{array}{l}\text { Hypothetical protein LOC100170830 } \\
\text { [Danio rerio] }\end{array}$ & NP_001124136 & 2.6 & 0.0325 \\
\hline $\begin{array}{l}\text { Hypothetical protein LOC368902 [Danio } \\
\text { rerio] }\end{array}$ & NP_001004525 & 2.0 & 0.0224 \\
\hline \multicolumn{4}{|l|}{ Line $R 3<$ line $K$ (14 genes) } \\
\hline $\begin{array}{l}\text { Lectin, galactoside-binding, soluble, } \\
\text { (galectin 1)-like3 [Danio rerio] }\end{array}$ & AAH55581 & 0.2 & 0.0466 \\
\hline $\begin{array}{l}\text { Nuclear cap-binding protein subunit } 2 \\
\quad \text { (Ncbp2 protein) [Danio rerio] }\end{array}$ & AAH83529 & 0.3 & 0.0165 \\
\hline $\begin{array}{l}\text { Histidyl-tRNA synthetase } 2 \text {, } \\
\text { mitochondrial (putative) [Danio rerio] }\end{array}$ & AAH76141 & 0.4 & 0.0165 \\
\hline $\begin{array}{l}\text { Sjogren syndrome antigen B } \\
\text { (autoantigen La) [Danio rerio] }\end{array}$ & NP_955841 & 0.4 & 0.0466 \\
\hline C-type lectin [Ctenopharyngodon idella] & ACS16044 & 0.4 & 0.0287 \\
\hline Zinc transporter ZIP9 [Danio rerio] & NP_001013558 & 0.4 & 0.0287 \\
\hline $\begin{array}{l}\text { CCT (chaperonin containing T-complex } \\
\text { polypeptide } 1 \text { ) epsilon subunit } \\
\text { [Carassius auratus] }\end{array}$ & BAA89277 & 0.4 & 0.0287 \\
\hline $\begin{array}{l}\text { Immunoglobulin binding protein } \\
\text { [Danio rerio] }\end{array}$ & AAT68067 & 0.4 & 0.0165 \\
\hline $\begin{array}{l}\text { Similar to coxsackie adenovirus } \\
\text { receptor-like [Danio rerio] }\end{array}$ & AAI62790 & 0.4 & 0.0401 \\
\hline Lamin-B receptor-like [Danio rerio] & XP_002664803 & 0.5 & 0.0403 \\
\hline Interferon $\gamma \mathbf{2 b}$ [Cyprinus carpio] & CAJ51089 & 0.5 & 0.0165 \\
\hline Dkc1 protein [Danio rerio] & AAH47840 & 0.5 & 0.0261 \\
\hline c-Myc [Cyprinus carpio] & BAA07129 & 0.5 & 0.0165 \\
\hline $\begin{array}{l}\text { TPA: interleukin } 13 \text { receptor alpha } 1 \\
\text { [Danio rerio] }\end{array}$ & CAI94933 & 0.5 & 0.0458 \\
\hline $\begin{array}{l}\text { EBNA1 binding protein 2-like [Danio } \\
\text { rerio] }\end{array}$ & AAT68147 & 0.5 & 0.0399 \\
\hline $\begin{array}{l}\text { ATP synthase oligomycin sensitivity } \\
\text { conferral protein [Danio rerio] }\end{array}$ & AAT68146 & 0.5 & 0.0462 \\
\hline $\begin{array}{l}\text { Coiled-coil domain containing } 43 \text { [Danio } \\
\quad \text { rerio] }\end{array}$ & AAH57502 & 0.5 & 0.0343 \\
\hline $\begin{array}{l}\text { Eukaryotic translation initiation factor } \\
\quad 4 \mathrm{~A} \text {, isoform } 1 \mathrm{~A} \text { [Danio rerio] }\end{array}$ & AAH48899 & 0.5 & 0.0165 \\
\hline Krr1 protein (Zgc:136398) [Danio rerio] & AAI17594 & 0.5 & 0.0221 \\
\hline $\begin{array}{l}\text { nucleolar protein } 1,120 \mathrm{kDa} \text { [Danio } \\
\text { rerio] }\end{array}$ & XP_001922354 & 0.5 & 0.0346 \\
\hline $\begin{array}{l}\text { Unnamed protein product [Tetraodon } \\
\text { nigroviridis] }\end{array}$ & CAG04699 & 0.5 & 0.0165 \\
\hline
\end{tabular}

microfibrillar-associated protein 4 (MFAP4)) were also highly expressed in line R3. Recently it has been reported that MFAP4 genes may play similar roles during the innate immune response in fish as ficolin genes in mammals, which are known to be involved in recognition and binding of carbohydrates in pathogens and the activation of complement leading to opsonization, leukocyte activation, and direct pathogen killing (Niu et al., 2011). Metallothioneins have various functions and were also found to be involved in immune responses including inflammation reactions (Coyle et al., 2002; Mocchegiani et al., 2006). The higher expression of genes involved in complement activation in the more resistant R3 line could indicate for the role of this immune mechanism in the response against CyHV-3. It is known that activation of the 


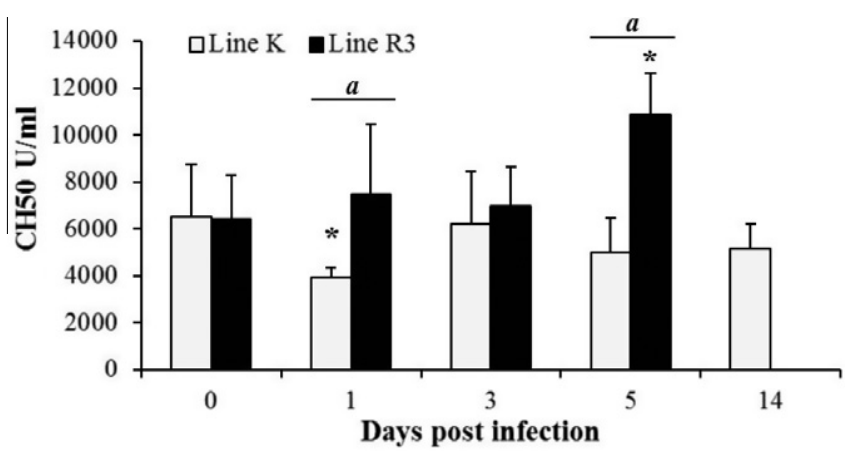

Fig. 2. Complement hemolytic activity in the classical pathway ( $\mathrm{CH} 50)$ analysis as measured in line K and R3. Data are shown as mean + SD of $n=5$ fish. Symbol $(*)$ indicates statistical differences $(p \leqslant 0.05)$ between infected and non-infected fish from the analyzed line. Symbol $(\underline{a})$ indicates statistical difference $(p \leqslant 0.05)$ between infected fish from 2 lines ( $\overline{\mathrm{K}}$ vs. R3) at the particular time point.

complement system can lead to neutralization of free viruses, phagocytosis of coated viral particles, lysis of virus-infected cells, and the generation of inflammation. Indeed, in vitro complement activation assay showed higher level of activation of complement in the classical pathway (CH50) in line $\mathrm{R} 3$ than in line $\mathrm{K}$.

Several genes which have functions in the MHC class I pathway such as invariant chain like protein 1 , invariant chain like protein 2 and $\beta-2$ microglobulin precursor were more highly expressed in line R3 than in line K. Genes involved in antigen recognition by $\mathrm{T}$ cells, such as T cell antigen receptor $\alpha$ chain VJC region and CD3 $\gamma / \delta$, were also highly expressed in the R3 line. The higher expression of genes involved in the MHC class I-restricted antigen processing in the more resistant R3 line might result in better cellmediated cytotoxic responses in this line. The higher activation of $\mathrm{CD}^{+} \mathrm{T}$ cells in the R3 line was also supported by our RT-qPCR analysis of T cell markers. Thus, differences in the levels of activation of $\mathrm{CD}^{+} \mathrm{T}$ cells between the two carp lines might result in higher or lower resistance to CyHV-3.

Chemokine CCL-C25a and CCL-C25ab were also highly expressed in the R3 line. In mammals, the CC chemokine ligand 25 (CCL25), also known as thymus-expressed chemokine (TECK), was described to be primarily expressed in dendritic cells of the thymus and mucosal epithelial cells. CCL25 was shown to play a role in T cells development (Vicari et al., 1997) and it is thought to be one of the key factors in the development of the adaptive mucosal immunity by targeting $\mathrm{T}$ cells to specific locations of infection (Kunkel et al., 2000; Meurens et al., 2006, 2007). Recently, it was demonstrated that the skin of common carp is the major portal of entry of CyHV-3 and that at the early stage of the disease, the virus replicates in skin epithelial cells (Costes et al., 2009). Very recently, the anti-CyHV-3 properties of carp skin mucus were described (Raj et al., 2011).

Fourteen genes were more highly expressed in carp from line $\mathrm{K}$ than in line R3. These genes included immune-related genes such as: galectin1-like 3, Sjogren syndrome antigen B, C-type lectin, immunoglobulin binding protein, interferon $\gamma 2 \mathrm{~b}$ and interleukin 13 receptor $\alpha 1$.

\subsection{The moderately susceptible $R 3$ line present higher activation of $C D 8^{+} T$ cells in the first phase of CyHV-3 infection than the susceptible $K$ line}

Mammalian cytotoxic T cells $\left(\mathrm{CD}^{+}\right)$, as part of the adaptive immune system, recognize virus-infected cells by the binding of their $\mathrm{T}$ cell receptors (TCR) to MHC class I molecules loaded with viral peptides. The mechanisms of cell-mediated cytotoxicity are quite conserved from fish to mammals (Fischer et al., 2006; Nakanishi et al., 2002; Utke et al., 2007) and T cell markers of common carp have been recently cloned and described (Forlenza et al., 2008a; Sun et al., 2007). This allowed us to use the expression of $\mathrm{T}$ cell markers to monitor the activity of cytotoxic $\mathrm{T}$ cells during the infection of carp with CyHV-3.

CD8 is known as a marker molecule for cytotoxic T cells. The expression of both duplicated common carp CD8 $\alpha$ and CD8 $\beta$ genes were studied in terms of cytotoxic T cell activity during CyHV-3 infection. Among all the isoforms studied, only CD8 $\beta 1$ showed a tendency for up-regulation from day 1 to day 5 p.i. in the R3 line and at day 5 p.i. in the $\mathrm{K}$ line. Interestingly an up-regulation of other isoforms - CD8 $\alpha 1, \mathrm{CD} 8 \alpha 2$ and CD $8 \beta 2$ - could not be statistically confirmed. In the case of CD8 $\beta 2$, a down-regulation of the expression was detected in carp from line $\mathrm{K}$ at day 3 p.i. It is well established that on mammalian T cells, CD8 glycoproteins are expressed as either $\alpha \alpha$ homodimers or as $\alpha \beta$ heterodimers (Witte et al., 1999). Human cells can also express $\beta \beta$ homodimers (Devine et al., 2000) but in contrast to $\alpha \alpha$ homodimers or $\alpha \beta$ heterodimers they are unable to bind to MHC class I. Based on common carp cDNA analysis of the predicted glycoprotein structure and based on the conservation of essential structural motifs, Forlenza et al. (2008a) suggested the possibility for an expression of CD8 $\beta \beta$ homodimers and a $\mathrm{CD} \beta$ signaling function in common carp. In this case it is likely that common carp could have different $\mathrm{CD}^{+} \mathrm{T}$ cells subpopulations, these could be functionally slightly different. This might explain the activation of only the CD8 $\beta 1$ isoform after CyHV3 viral infection. This is also in line with data reported by Forlenza et al. (2008a) which demonstrated a differential expression of CD8 isoforms in common carp during spring viraemia of carp virus (SVCV) infection.

Both TCR $\alpha 1$ and TCR $\alpha 2$ genes were up-regulated at day 1 p.i. in carp from line R3 but not from line K. On day 5 p.i. TCR $\alpha 1$ and TCR $\alpha 2$ genes were down-regulated in the R3 line carp. The down-regulation occurred even faster in the $\mathrm{K}$ line carp, which showed lower levels of TCR $\alpha 2$ on day 3 p.i. A high up-regulation of the transcription of both TCR $\alpha$ and TCR $\beta$ genes was observed at day 1 after DNA vaccination of Japanese flounder against the hirame rhabdovirus (HIRRV). However 7 days after vaccination the expression levels of these genes decreased and returned to the level of gene expression of non-vaccinated fish (Takano et al., 2004). Infection of common carp with SVCV revealed no significant changes of gene expression of both TCR $\alpha 1$ and TCR $\alpha 2$ genes after primary infection, whereas the two TCR genes were already upregulated $6 \mathrm{~h}$ post-secondary infection and remained high until day 7 p.i. (Forlenza et al., 2008a).

The up-regulation of both TCR genes and the CD $\beta 1$ gene in the first phase of infection, which was observed in the R3 line but not in the $\mathrm{K}$ line, might indicate a higher activation of $\mathrm{CD} 8^{+} \mathrm{T}$ cells in this line, which could result in a better immune response against the CyHV-3 virus and finally could contribute to the higher survival rate.

\subsection{Differential kinetics of expression of cytokine genes between carp lines $R 3$ and $K$}

IL- $1 \beta$ is one of the best described pro-inflammatory cytokines in fish. An up-regulation of IL1- $\beta 1$ was described in various fish species during infection with ectoparasites (Forlenza et al., 2008b; Gonzalez et al., 2007; Sigh et al., 2004), with the blood parasite Trypanoplasma borreli (Saeij et al., 2003), bacteria (Mohanty and Sahoo, 2010), and viruses (Purcell et al., 2004; Tafalla et al., 2005). CyHV-3 infection clearly up-regulated IL-1 $\beta$ expression in carp from line K (at day 3 p.i.) and R3 (at day 5 p.i.). Faster up-regulation of IL-1 $\beta$ expression in carp from line $K$ (peak at day 3 p.i.) compared to carp from line R3 (peak at day 5 p.i.) might be correlated with the difference in virus levels between the two lines. Indeed, the 

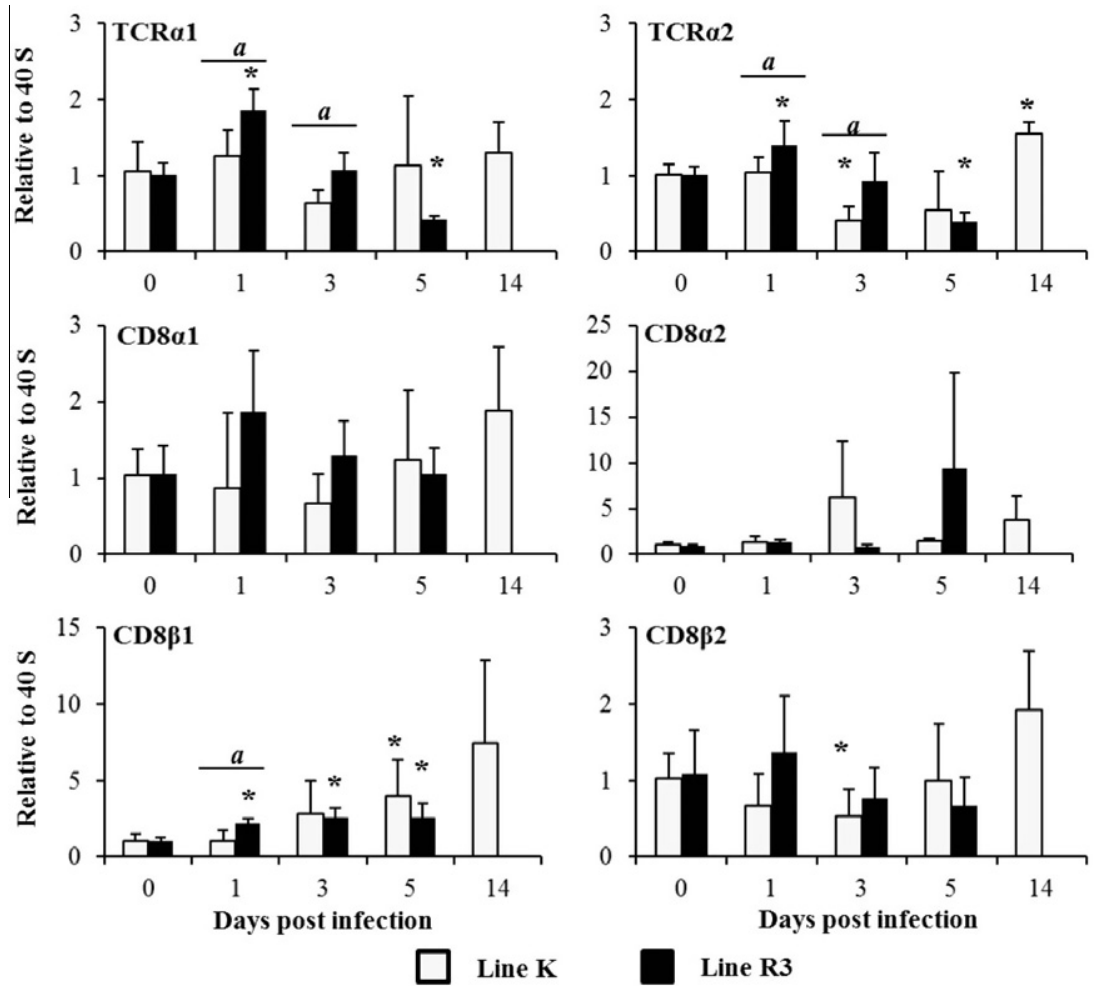

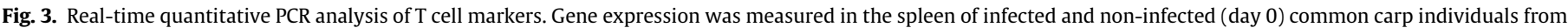

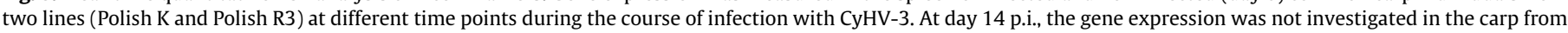

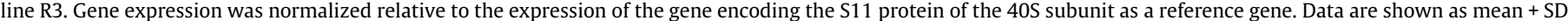

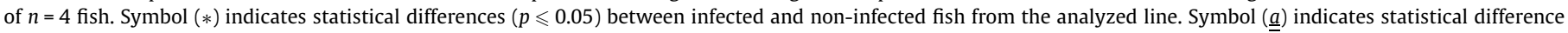
$(p \leqslant 0.05)$ between infected fish from 2 lines (K vs. R3) at the particular time point.

number of virus copies as measured at day 3 p.i., was significantly higher in the $\mathrm{K}$ line than in the R3 line, while at day 5 p.i. the virus level in the R3 line increased and was on the same level as in the $\mathrm{K}$ line (data not shown). The transcription level of IL1- $\beta 1$ returned to initial values by day 14 p.i. The striking differences in the transcription of IL- $1 \beta$ between carp lines K and R3 on day 5 p.i. (more than 5 -fold) indicate that a higher stimulation of the immune response could be an important factor explaining the differences between these two carp lines in the resistance to an infection with CyHV-3.

Another important pro-inflammatory cytokine is IL-12. In carp, a single gene for IL-12p35 and three highly distinct genes encoding for IL-12p40 (a-c) were identified (Huising et al., 2006). Recently, an up-regulation of the genes encoding for IL-12p35 and only the IL-12p40b isoform was revealed during an infection of carp with SVCV (Forlenza et al., 2008a). We observed a significant down-regulation of IL-12p35 expression after CyHV-3 infection in carp from the $\mathrm{K}$ line (at day 3 and 5 p.i.) but not in carp from the R3 line. In addition, we observed an up-regulation of IL-12p35 in carp from the R3 line at day 3 p.i., although this up regulation could not be confirmed as statistically significant owing to high individual variations in the transcription levels. The cytokine IL- 12 stimulates the activity of cytotoxic T cells and NK cells as well as the secretion of IFN $\gamma$ and TNF. A down-regulation of IL12-p35 expression in carp from the $\mathrm{K}$ line coincides with a decreasing level of $\mathrm{T}$ cell marker expression, which might indicate a lower cytotoxic response in this line.

In mammals, IL-10 is known to be an anti-inflammatory cytokine which regulates the inflammatory response, however the direct function of IL-10 in fish is less known. Some studies on IL-10 gene expression in fish also suggested its role in the down-regulation of the inflammatory response (Forlenza, 2009; Ingerslev et al., 2009; Raida and Buchmann, 2008a). We observed a relatively high up-regulation of the expression of IL-10 on day 5 p.i. and an elevated level was maintained until day 14 p.i. This up-regulation of IL-10 might reflect an activation of humoral immunity and an inhibition of the inflammatory response.

The mammalian IL-6 family of cytokines are major players in hematopoiesis, as well as in the neuroendocrine and immune systems, and have pro- and anti-inflammatory functions. The IL6M17 gene was shown to be involved in teleost immune responses (Fujiki et al., 2003; Wang and Secombes, 2009). In rainbow trout IL6 expression was up-regulated by both LPS and $\beta$-glucan stimulation in vivo (Lovoll et al., 2007) and after Yersinia ruckeri infection (Raida and Buchmann, 2008b) which suggests a role as a proinflammatory mediator. We observed an up-regulation and a much higher level in the expression of the IL-6M17 gene in carp from the R3 line compared to carp from the $\mathrm{K}$ line, although this difference was only statistically significant at day 5 p.i., owing to high individual variations in the R3 line. Nevertheless it could be speculated that the level of macrophage and T-cell activation (main IL-6 secreting cells) in the R3 line was much more efficient than that in the $\mathrm{K}$ line.

Interestingly, our results showed no differences in IFN $\alpha \beta$ gene expression in both lines. An up-regulation of this gene was not seen in the microarray analysis and it was not observed by RTqPCR analysis either. Nevertheless our microarray analysis revealed up-regulation of several genes activated by the type I IFNs. In fish, multiple forms of IFNs which are differentially induced during stimulation has been described (Sun et al., 2009). Very recently new genes of common carp type I IFNs were cloned and showed different expression profiles during CyHV-3 infection (Adamek et al., in preparation). It could therefore be speculated that primers and probes used in our study do not amplify all IFN genes present in carp and involved in the immune response against CyHV-3. 

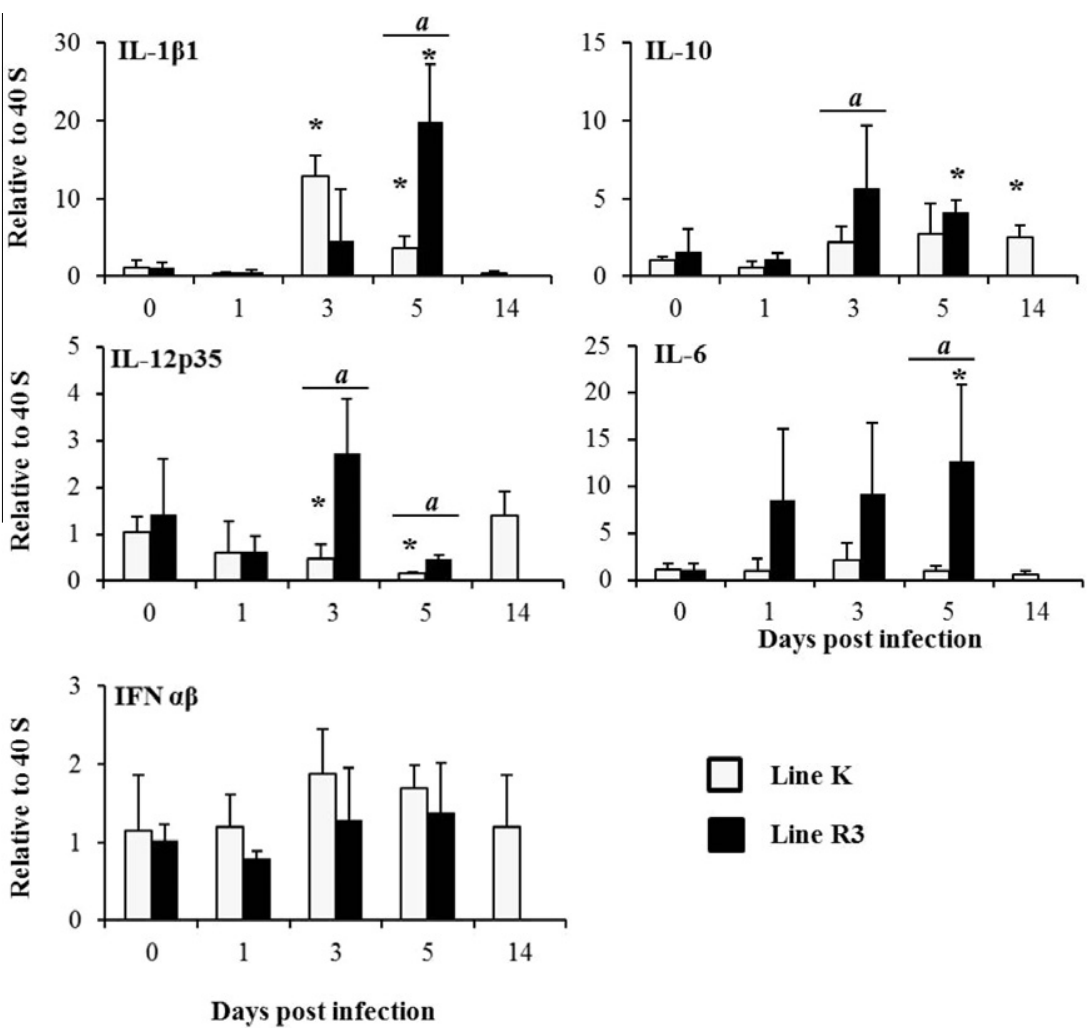

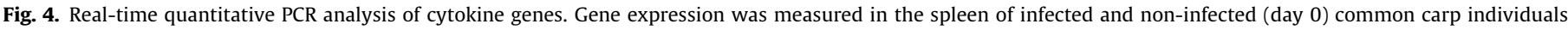

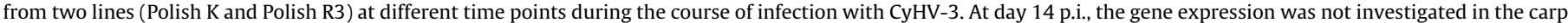

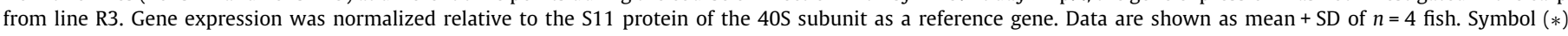

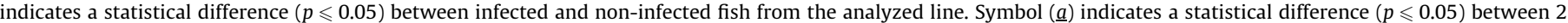
lines of infected fish (K vs. R3) at a particular time point.

In conclusion, this is the first study of the genetic basis underlying the common carp immune response to the CyHV-3 virus. We identified a group of genes which were significantly regulated by CyHV-3 in both carp lines. We believe that these genes can serve as CyHV-3 infection markers for primary testing of different vaccines. Our study also revealed that differences in resistance to CyHV-3 between the two carp lines can be correlated with differentially expressed immune-related genes. The kinetics of expression of the immune-related genes indicate for a higher activation of cytotoxic T cells in the more resistant R3 line. Altogether, our results add to the understanding of the common carp immune response against the CyHV-3 virus and provide knowledge for developing future vaccines.

\section{Acknowledgements}

This work was funded by a Polish-Japanese Joint Research Project from 2009-2011 (BWZ/384/JSK/JSPS/09) including a JSPS fellowship for K. Rakus, K. Rakus and L. Palmeira are currently postdoctoral fellows of the University of Liège (Belgium). M. Adamek and G. Brogden are Research Fellows of the European Community's Seventh Framework Programme (FP7/2007-2013) under Grant agreement number PITN-GA-2008-214505 (NEMO). We thank A. Sych, D. Rajba-Nikiel and J. Krzempek for help with in vitro complement analysis.

\section{References}

Aoki, T., Hirono, I., Kurokawa, K., Fukuda, H., Nahary, R., Eldar, A., et al., 2007. Genome sequences of three koi herpesvirus isolates representing the expanding distribution of an emerging disease threatening koi and common carp worldwide. Journal of Virology 81, 5058-5065
Baerwald, M.R., Welsh, A.B., Hedrick, R.P., May, B., 2008. Discovery of genes implicated in whirling disease infection and resistance in rainbow trout using genome-wide expression profiling. BMC Genomics 9, 1-11.

Benjamini, Y., Hochberg, Y., 1995. Controlling the false discovery rate: a practical and powerful approach to multiple testing. Journal of the Royal Statistical Society Series B 57, 289-300.

Bianchet, M.A., Odom, E.W., Vasta, G.R., Amzel, L.M., 2002. A novel fucose recognition fold involved in innate immunity. Nature Structural Biology 9, 628-634.

Bilodeau-Bourgeois, L., Bosworth, B.G., Peterson, B.C., 2008. Differences in mortality, growth, lysozyme, and toll-like receptor gene expression among genetic groups of catfish exposed to virulent Edwardsiella ictaluri. Fish \& Shellfish Immunology 24, 82-89.

Bode, J.G., Ludwig, S., Ehrhardt, C., Erhardt, A., Albrecht, U., Schaper, F., et al., 2003. IFN- $\alpha$ antagonistic activity of HCV core protein involves induction of suppressor of cytokine signaling-3. The FASEB Journal 17, 488-490.

Bolstad, B.M., Irizarry, R.A., Astrand, M., Speed, T.P., 2003. A comparison of normalization methods for high density oligonucleotide array data based on bias and variance. Bioinformatics 19, 185-193.

Brazma, A., Hingamp, P., Quackenbush, J., Sherlock, G., Spellman, P., Stoeckert, C., et al., 2001. Minimum information about a microarray experiment (MIAME) toward standards for microarray data. Nature Genetics 29, 365-371.

Bretzinger, A., Fischer-Scheri, T., Oumouna, M., Hoffman, R., Truyen, U., 1999. Mass mortalities in koi carp, Cyprinus carpio, associated with gill and skin disease. Bulletin of European Association of Fish Pathology 19, 182-185.

Chan, T., Barra, N.G., Lee, A.J., Ashkar, A.A., 2011. Innate and adaptive immunity against herpes simplex virus type 2 in the genital mucosa. Journal of Reproductive Immunology 88, 210-218.

Collet, B., Bain, N., Prevost, S., Besinque, G., McBeath, A., Snow, M., et al., 2008. Isolation of an Atlantic salmon (Salmo salar) signal transducer and activator of transcription STAT1 gene: Kinetics of expression upon ISAV or IPNV infection. Fish \& Shellfish Immunology 25, 861-867.

Costes, B., Stalin Raj, V., Michel, B., Fournier, G., Thirion, M., Gillet, L., et al., 2009. The major portal of entry of Koi Herpesvirus in Cyprinus carpio is the skin. Journal of Virology 83, 2819-2830.

Coyle, P., Philcox, J.C., Carey, L.C., Rofe, A.M., 2002. Metallothionein: the multipurpose protein. Cellular and Molecular Life Sciences 59, 627-647.

Davison, A.J., Eberle, R., Ehlers, B., Hayward, G.S., McGeoch, D.J., Minson, A.C., et al., 2009. The order Herpesvirales. Archives of Virology 154, 171-177.

D’Cunha, J., Knight Jr., E., Haas, A.L., Truitt, R.L., Borden, E.C., 1996. Immunoregulatory properties of ISG15, an interferon-induced cytokine 
Proceedings of the National Academy of Sciences of the United States of America 93, 211-215.

Devine, L., Kieffer, L.J., Aitken, V., Kavathas, P.B., 2000. Human CD8 beta, but not mouse CD8 beta, can be expressed in the absence of CD8 alpha as a beta beta homodimer. Journal of Immunology 164, 833-838.

Dixon, P.F., Joiner, C.L., Way, K., Reese, R.A., Jeney, G., Jeney, Z., 2009. Comparison of the resistance of selected families of common carp, Cyprinus carpio L., to koi herpesvirus: preliminary study. Journal of Fish Diseases 32, 1035-1039.

Fenner, J.E., Starr, R., Cornish, A.L., Zhang, J.-G., Metcalf, D., Schreiber, R.D., et al. 2006. Suppressor of cytokine signaling 1 regulates the immune response to infection by a unique inhibition of type I interferon activity. Nature Immunology 7, 33-39.

Fischer, U., Utke, K., Somamoto, T., Köllner, B., Ototake, M., Nakanishi, T., 2006. Cytotoxic activities of fish leucocytes. Fish \& Shellfish Immunology 20, 209226.

Forlenza, M., 2009. Immune response of carp. A molecular and cellular approach to infections. PhD Thesis, Wageningen University, Wageningen, The Netherlands.

Forlenza, M., de Carvalho Dias, J.D.A., Vesely, T., Pokorova, D., Savelkoul, H.F.J. Wiegertjes, G.F., 2008a. Transcription of signal-3 cytokines, IL-12 and IFN $\alpha \beta$, coincides with the timing of $C D 8 \alpha \beta$ up-regulation during viral infection of common carp (Cyprinus carpio L.). Molecular Immunology 45, 1531-1547.

Forlenza, M., Walker, P.D., de Vries, B.J., Bonga, S.E.W., Wiegertjes, G.F., 2008b. Transcriptional analysis of the common carp (Cyprinus carpio L.) immune response to the fish louse Argulus japonicus Thiele (Crustacea: Branchiura). Fish \& Shellfish Immunology 25, 76-83.

Fujiki, K., Nakao, M., Dixon, B., 2003. Molecular cloning and characterisation of carp (Cyprinus carpio) cytokine-like cDNA that shares sequence similarity with IL-6 subfamily cytokines CNTF, OSM and LIF. Developmental and Comparative Immunology 27, 127-136.

Gentleman, R.C., Carey, V.J., Bates, D.M., Bolstad, B., Dettling, M., Dudoit, S., et al. 2004. Bioconductor: open software development for computational biology and bioinformatics. Genome Biology 5, R80.

Gilad, O., Yun, S., Zagmutt-Vergara, F.J., Leutenegger, C.M., Bercovier, H., Hedrick R.P., 2004. Concentrations of a koi herpesvirus (KHV) in tissues of experimentally infected Cyprinus carpio koi as assessed by real-time TaqMan PCR. Diseases of Aquatic Organisms 60, 179-187.

Gonzalez, S.F., Buchmann, K., Nielsen, M.E., 2007. Real-time gene expression analysis in carp (Cyprinus carpio L.) skin: Inflammatory responses caused by the ectoparasite Ichthyophthirius multifiliis. Fish \& Shellfish Immunology 22, 641 650.

Harty, R.N., Pitha, P.M., Okumura, A., 2009. Antiviral activity of innate immune protein ISG15. Journal of Innate Immunity 1, 397-404.

Hedrick, R.P., Gilad, O., Yun, S., Spangenberg, J.V., Marty, G.D., Nordhausen, R.W. et al., 2000. A herpesvirus associated with mass mortality of juvenile and adult koi, a strain of common carp. Journal of Aquatic Animals and Health 12, 44-57.

Honda, S., Kashiwagi, M., Miyamoto, K., Takei, Y., Hirose, S., 2000. Multiplicity Structures, and Endocrine and Exocrine Natures of Eel Fucose-binding Lectins. Journal of Biological Chemistry 275, 33151-33157.

Huising, M.O., van Schijndel, J.E., Kruiswijk, C.P., Nabuurs, S.B., Savelkoul, H.F.J., Flik G., et al., 2006. The presence of multiple and differentially regulated interleukin12 p40 genes in bony fishes signifies an expansion of the vertebrate heterodimeric cytokine family. Molecular Immunology 43, 1519-1533.

Ingerslev, H.C., Rønneseth, A., Pettersen, E.F., Wergeland, H.I., 2009. Differentia expression of immune genes in Atlantic salmon (Salmo salar L.) challenged intraperitoneally or by cohabitation with IPNV. Scand. Journal of Immunology $69,90-98$.

Irnazarow, I., 1995. Genetic variability of Polish and Hungarian carp lines. Aquaculture 129, 215-219.

Katze, M.G., He, Y., Gale, M., 2002. Viruses and interferon: a fight for supremacy. Nature Reviews Immunology 2, 675-687.

Kerscher, O., Felberbaum, R., Hochstrasser, M., 2006. Modification of proteins by ubiquitin and ubiquitin-like proteins. Annual Review of Cell and Developmental Biology 22, 159-180.

Kunkel, E.J., Campbell, J.J., Haraldsen, G., Pan, J., Boisvert, J., Roberts, A.I., et al., 2000 Lymphocyte CC chemokine receptor 9 and epithelial thymus-expressed chemokine (TECK) expression distinguish the small intestinal immune compartment: epithelial expression of tissue-specific chemokines as an organizing principle in regional immunity. Journal of Experimental Medicine 192, 761-768.

Liu, M., Reimschuessel, R., Hassel, B.A., 2002. Molecular cloning of the fish interferon stimulated gene, 15 kDa (ISG15) orthologue: a ubiquitin-like gene induced by nephrotoxic damage. Gene 298, 129-139.

Livak, K.J., Schmittgen, T.D., 2001. Analysis of relative gene expression data using real-time quantitative PCR and the $2(\mathrm{~T})(-$ Delta Delta $\mathrm{C}$ ) method. Methods 25 $402-408$

Lovoll, M., Fischer, U., Mathisen, G.S., Bogwald, J., Ototake, M., Dalmo, R.A., 2007. The C3 subtypes are differentially regulated after immunostimulation in rainbow trout, but head kidney macrophages do not contribute to C3 transcription. Veterinary Immunology and Immunopathology 117, 284-295.

Meurens, F., Berri, M., Whale, J., Dybvig, T., Strom, S., Thompson, D., et al., 2006. Expression of TECK/CCL25 and MEC/CCL28 chemokines and their respective receptors CCR9 and CCR10 in porcine mucosal tissues. Veterinary Immunology and Immunopathology 113, 313-327.

Meurens, F., Whale, J., Brownlie, R., Dybvig, T., Thompson, D.R., Gerdts, V., 2007. Expression of mucosal chemokines TECK/CCL25 and MEC/CCL28 during feta development of the ovine mucosal immune system. Immunology 120, 544-555.
Michel, B., Fournier, G., Lieffrig, F., Costes, B., Vanderplasschen, A., 2010. Cyprinid herpesvirus 3. Emerging Infectious Diseases 16, 1835-1843.

Mocchegiani, E., Costarelli, L., Giacconi, R., Cipriano, C., Muti, E., Malavolta, M., 2006. Zinc-binding proteins (metallothionein and $\alpha-2$ macroglobulin) and immunosenescence. Experimental Gerontology 41, 1094-1107.

Mohanty, B.R., Sahoo, P.K., 2010. Immune responses and expression profiles of some immune-related genes in Indian major carp, Labeo rohita to Edwardsiella tarda infection. Fish \& Shellfish Immunology 28, 613-621.

Mossman, K.L., Ashkar, A.A., 2005. Herpesviruses and the innate immune response. Viral Immunology 18, 267-281.

Nakanishi, T., Fischer, U., Dijkstra, J.M., Hasegawa, S., Somamoto, T., Okamoto, N., et al., 2002. Cytotoxic T cell function in fish. Developmental and Comparative Immunology 26, 131-139.

Negenborn, J., 2009. Klinisch-chemische parameter im blut und urin von karpfen unter infection mit dem koi-herpesvirus. PhD Thesis, University of Veterinary Medicine in Hannover, Hannover, Germany.

Neukirch, M., Böttcher, R., Bunnajirakul, S., 1999. Isolation of a virus from koi with altered gills. Bulletin of European Association of Fish Pathology 19, 221-223.

Niu, D., Peatman, E., Liu, H., Lu, J., Kucuktas, H., Liu, S., et al., 2011. Microfibrillarassociated protein 4 (MFAP4) genes in catfish play a novel role in innate immune responses. Developmental and Comparative Immunology 35, 568-579.

Ødegård, J., Olesen, I., Dixon, P., Jeney, Z., Nielsen, H.-M., Way, K., et al., 2010. Genetic analysis of common carp (Cyprinus carpio) strains. II: Resistance to koi herpesvirus and Aeromonas hydrophila and their relationship with pond survival. Aquaculture 304, 7-13.

Oshansky, C.M., Krunkosky, T.M., Barber, J., Jones, L.P., Tripp, R.A., 2009. Respiratory syncytial virus proteins modulate suppressors of cytokine signaling 1 and 3 and the type I interferon response to infection by a toll-like receptor pathway. Viral Immunology 22, 147-161.

Perelberg, A., Ilouze, M., Kotler, M., Steinitz, M., 2008. Antibody response and resistance of Cyprinus carpio immunized with cyprinid herpes virus 3 (CyHV-3). Vaccine 26, 3750-3756.

Pokorova, D., Vesely, T., Piackova, V., Reschova, S., Hulova, J., 2005. Current knowledge on koi herpesvirus (KHV): a review. Veterinary Medicine (Czech) 50, 139-147.

Pothlichet, J., Chignard, M., Si-Tahar, M., 2008. Cutting edge: innate immune response triggered by influenza a virus is negatively regulated by SOCS1 and SOCS3 through a RIG-I/IFNARI-dependent pathway. Journal of Immunology 180, 2034-2038.

Purcell, M.K., Kurath, G., Garver, K.A., Herwig, R.P., Winton, J.R., 2004. Quantitative expression profiling of immune response genes in rainbow trout following infectious haematopoletic necrosis virus (IHNV) infection or DNA vaccination. Fish \& Shellfish Immunology 17, 447-462.

R Development Core Team, 2011. R: A Language and Environment for Statistical Computing. R Foundation for Statistical Computing. http://www.R-project.org.

Raida, M.K., Buchmann, K., 2008a. Development of adaptive immunity in rainbow trout, Oncorhynchus mykiss (Walbaum) surviving an infection with Yersinia ruckeri. Fish \& Shellfish Immunology 25, 533-541.

Raida, M.K., Buchmann, K., 2008b. Bath vaccination of rainbow trout (Oncorhynchus mykiss Walbaum) against Yersinia ruckeri: effects of temperature on protection and gene expression. Vaccine 26, 1050-1062.

Raj, S.V., Fournier, G., Rakus, K., Ronsmans, M., Ouyang, P., Michel, B., et al., 2011. Skin mucus of Cyprinus carpio inhibits cyprinid herpesvirus 3 binding to epidermal cells. Vet. Res. 42, 92.

Rakus, K.Ł., Wiegertjes, G.F., Adamek, M., Siwicki, A.K., Lepa, A., Irnazarow, I., 2009. Resistance of common carp (Cyprinus carpio L.) to Cyprinid herpesvirus-3 is influenced by major histocompatibility $(\mathrm{MH})$ class II $B$ gene polymorphism. Fish \& Shellfish Immunology 26, 737-743.

Reed, L.J., Meunch, H.A., 1938. A simple method of estimating fifty percent endpoints. American Journal of Hygiene 24, 493-497.

Ritchie, M.E., Silver, J., Oshlack, A., Silver, J., Holmes, M., Diyagama, D., et al., 2007. A comparison of background correction methods for two-colour microarrays. Bioinformatics 23, 2700-2707.

Robertsen, B., 2006. The interferon system of teleost fish. Fish \& Shellfish Immunology 20, 172-191.

Rombout, J.H.W.M., Huttenhuis, H.B.T., Picchietti, S., Scapigliati, G., 2005. Phylogeny and ontogeny of fish leucocytes. Fish \& Shellfish Immunology 16, 441-455.

Rossi, D., Zlotnik, A., 2000. The biology of chemokines and their receptors. Annual Review of Immunology 18, 217-242.

Saeij, J.P.J., de Vries, B.J., Wiegertjes, G.F., 2003. The immune response of carp to Trypanoplasma borreli: kinetics of immune gene expression and polyclonal lymphocyte activation. Developmental and Comparative Immunology 27, 859874.

Saito, T., Hatada, M., Iwanaga, S., Kawabata, S.I., 1997. A Newly Identified Horseshoe Crab Lectin with Binding Specificity to O-antigen of Bacterial Lipopolysaccharides. Journal of Biological Chemistry 272, 30703-30708.

Shapira, Y., Magen, Y., Zak, T., Kotler, M., Hulata, G., Levavi-Sivan, B., 2005. Differential resistance to koi herpes virus (KHV)/carp interstitial nephritis and gill necrosis virus (CNGV) among common carp (Cyprinus carpio L.) strains and crossbreds. Aquaculture 245, 1-11

Sigh, J., Lindenstrom, T., Buchmann, K., 2004. Expression of pro-inflammatory cytokines in rainbow trout (Oncorhynchus mykiss) during an infection with Ichthyophthirius multifiliis. Fish \& Shellfish Immunology 17, 75-86.

Smyth, G.K., 2004. Linear models and empirical Bayes methods for assessing diffrential expression in microarray experiments. Statastiacl Application of Genetics and Molecular Biology 3, Article 3. 
76

K.t. Rakus et al./Developmental and Comparative Immunology 37 (2012) 65-76

Starr, R., Willson, T.A., Viney, E.M., Murray, L.J.L., Rayner, J.R., Jenkins, B.J., et al., 1997. A family of cytokine-inducible inhibitors of signaling. Nature 387, 917 921.

Sun, B., Robertsen, B., Wang, Z., Liu, B., 2009. Identification of an Atlantic salmon IFN multigene cluster encoding three IFN subtypes with very different expression properties. Developmental and Comparative Immunology 33, 547-558.

Sun, X.F., Shang, N., Hu, W., Wang, Y.P., Guo, Q.L., 2007. Molecular cloning and characterization of carp (Cyprinus carpio L.) CD8 beta and CD4-like genes. Fish \& Shellfish Immunology 23, 1242-1255.

Tafalla, C., Coll, J., Secombes, C.J., 2005. Expression of genes related to the early immune response in rainbow trout (Oncorhynchus mykiss) after viral haemorrhagic septicemia virus (VHSV) infection. Developmental and Comparative Immunology 29, 615-626.

Takano, T., Iwahori, A., Hirono, I., Aoki, T., 2004. Development of a DNA vaccine against hirame rhabdovirus and analysis of the expression of immune-related genes after vaccination. Fish \& Shellfish Immunology 17, 367-374.

Utke, K., Bergmann, S., Lorenzen, N., Köllner, B., Ototake, M., Fischer, U., 2007. Cellmediated cytotoxicity in rainbow trout, Oncorhynchus mykiss, infected with viral haemorrhagic septicaemia virus. Fish \& Shellfish Immunology 22, 182-196.

Verrier, E.R., Langevin, C., Benmansour, A., Boudinot, P., 2011. Early antiviral response and virus-induced genes in fish. Developmental and Comparative Immunology 35, 101-111.

Vicari, A.P., Figueroa, D.J., Hedrick, J.A., Foster, J.S., Singh, K.P., Menon, S., et al., 1997. TECK: A novel CC chemokine specifically expressed by thymic dendritic cells and potentially involved in T cell development. Immunity 7, 291-301.

Waltzek, T.B., Kelley, G.O., Alfaro, M.E., Kurobe, T., Davison, A.J., Hedrick, R.P., 2009. Phylogenetic relationships in the family Alloherpesviridae. Diseases of Aquatic Organisms 84, 179-194.
Wang, T., Secombes, C.J., 2009. Identification and expression analysis of two fishspecific IL-6 cytokine family members, the ciliary neurotrophic factor (CNTF)like and M17 genes, in rainbow trout Oncorhynchus mykiss. Molecular Immunology 46, 2290-2298.

Wills, M.R., Carmichael, A.J., Sinclair, J., Sissons, J.P., 2007. Immunobiology and host response. In: Arvin, A., Campadelli-Fiume, G., Mocarski, E., Moore, P.S., Roizman, B., Whitley, R., Yamanishi, K. (Eds.), Human Herpesviruses: Biology, Therapy and Immunoprophylaxis. Cambridge University Press, Cambridge, Chapter 43.

Witte, T., Spoerl, R., Chang, H.C., 1999. The CD8 beta ectodomain contributes to the augmented coreceptor function of CD8 alpha beta heterodimers relative to CD8 alpha alpha homodimers. Cellular Immunology 191, 90-96.

Yang, Y.H., Thorne, N.P. 2003. Normalization for two-color cDNA microarray data. In: Goldstein, D.R. (Ed.), Science and Statistics A Festschrift for Terry Speed IMS Lecture Notes - Monograph Series, pp. 403-418.

Yano, T. 1992. Assays of hemolytic complement activity. In: Stolen, J.S. Fletcher, T.C., Anderson, D.P., Kaatari, S.L., Rowley A.F. (Eds.), Techniques in Fish Immunology, vol. 2, pp. 131-141

Yasuike, M., Takano, T., Kondo, H., Hirono, I., Aoki, T., 2010. Differential gene expression profiles in Japanese flounder (Paralichthys olivaceus) with different susceptibilities to edwardsiellosis. Fish \& Shellfish Immunology 29, 747-752.

Zhang, Y.B., Gui, J.F., 2004. Identification of two novel interferon-stimulated genes from cultured $C A B$ cells induced by UV-inactivated grass carp hemorrhage virus. Diseases of Aquatic Organisms 60, 1-9.

Zhao, D.C., Yan, T., Li, L., You, S., Zhang, C., 2007. Respiratory syncytial virus inhibits interferon-ainducible signaling in macrophage-like U937 cells. Journal of Infection 54, 393-398. 